\title{
1 Non-breeding waterbirds benefit from protected areas when adjusting their 2 distribution to climate warming
}

Elie Gaget ${ }^{1}$, Diego Pavón-Jordán ${ }^{2}$, Alison Johnston ${ }^{3,4}$, Aleksi Lehikoinen ${ }^{5}$, Wesley M. Hochachka ${ }^{3}$, Brett K. Sandercock ${ }^{2}$, Alaaeldin Soultan ${ }^{6}$, Hichem Azafzaf $^{7}$, Nadjiba Bendjedda ${ }^{8}$, Taulant Bino ${ }^{9}$, Luca Božič ${ }^{10}$, Preben Clausen ${ }^{11}$, Mohamed Dakki ${ }^{12}$, Koen Devos ${ }^{13}$, Cristi Domsa ${ }^{14}$, Vitor Encarnação ${ }^{15}$, Kiraz Erciyas-Yavuz ${ }^{16}$, Sándor Faragó ${ }^{17}$, Teresa Frost ${ }^{18}$, Clemence Gaudard ${ }^{19}$, Lívia Gosztonyi ${ }^{17}$, Fredrik Haas $^{20}$, Menno Hornman ${ }^{21}$, Tom Langendoen ${ }^{22}$, Christina leronymidou ${ }^{23}$, Vasiliy A. Kostyushin ${ }^{24}$, Lesley J. Lewis ${ }^{25}$, Svein-Håkon Lorentsen², Leho Luiujoe ${ }^{26}$, Włodzimierz Meissner ${ }^{27}$, Tibor Mikuska ${ }^{28}$, Blas Molina ${ }^{29}$, Zuzana Musilová ${ }^{30}$, Viktor Natykanets ${ }^{31}$, Jean-Yves Paquet ${ }^{32}$, Nicky Petkov ${ }^{33}$, Danae Portolou $^{34}$, Jozef Ridzoň ${ }^{35}$, Samir Sayoud ${ }^{8}$, Marko Šćiban ${ }^{36}$, Laimonas Sniauksta ${ }^{37}$, Antra Stīpniece ${ }^{38}$, Nicolas Strebel $^{39}$, Norbert Teufelbauer ${ }^{40}$, Goran Topić ${ }^{41}$, Danka Uzunova ${ }^{42}$, Andrej Vizi ${ }^{43}$, Johannes Wahl $^{44}$, Marco Zenatello ${ }^{45}$ \& Jon E. Brommer ${ }^{1}$

${ }^{1}$ Department of Biology, University of Turku, Turku, Finland

${ }^{2}$ Department of Terrestrial Ecology, Norwegian Institute for Nature Research (NINA), P.O. Box 5685 Sluppen, N-7485 Trondheim, Norway

${ }^{3}$ Cornell Lab of Ornithology, Cornell University, Ithaca, NY 14850

${ }^{4}$ ConservationScience Group, Department of Zoology, University of Cambridge, CB2 3QZ Cambridge, United Kingdom

${ }^{5}$ The Finnish Museum of Natural History, P.O. Box 17, 00014 University of Helsinki, Finland;

${ }^{6}$ Department of Ecology, Swedish University of Agricultural Sciences, Uppsala, Sweden

${ }^{7}$ Les Amies des Oiseaux (AAO), Ariana, Tunisia

${ }^{8}$ Direction générale des Forêts, Ben Aknoun, Alger, Algérie

${ }_{9}^{9}$ Albaninan Ornithological Society, Bulevardi "Gjergj Fishta", Kulla nr.2, kati 4, hyrja 18, Tirana, Albania

${ }^{10}$ Društvo za opazovanje in proučevanje ptic Slovenije (DOPPS), Tržaška cesta 2, SI-1000 Ljubljana, Slovenia

${ }^{11}$ Department of Biosciences, Aarhus University, Rønde, Denmark

${ }^{12}$ Scientific Institute, Mohammed V University of Rabat, Av. Ibn Battota, 10106 Rabat-Agdal,

Morocco

${ }^{13}$ Research Institute for Nature and Forest, Brussel, Belgium 
${ }^{15}$ Instituto da Conservação da Natureza e das Florestas, IP (ICNF), Centro de Estudos de Migrações e Proteção de Aves (CEMPA), Lisboa, Portugal

${ }^{16}$ Ornithological Research Center, Ondokuz Mayis University, 55139 Samsun, Turkey

${ }^{17}$ Institut für Wildwirtschaft und Wirbeltier Zoologie, Universiät Sopron, H-9400 Sopron, Bajcsy-

Zsilinszky u. 4, Ungarn

${ }^{18}$ British Trust for Ornithology, Thetford, UK

${ }^{19}$ LPO-BirdLife France, Fonderies Royales, Rochefort Cedex, France

${ }^{20}$ Department of Biology, Lund University, Lund, Sweden

${ }^{21}$ Sovon Dutch Centre for Field Ornithology, Nijmegen, The Netherlands

${ }^{22}$ Wetlands International, Ede, The Netherlands

${ }^{23}$ BirdLife Cyprus, P.O Box 12026 2340, Nicosia, Cyprus

${ }^{24}$ Monitoring and animal conservation department Schmalgausen Institute of Zoology, NAS of

Ukraine, vul. B. Khmelnytskogo, 15, Kyiv, 01030 Ukraine

${ }^{25} \mathrm{I}$-WeBS Office, BirdWatch Ireland, Wicklow, Ireland

${ }^{26}$ Department of Zoology, Estonian University of Life Sciences, Tartu, Estonia

${ }^{27}$ Department of Vertebrate Ecology and Zoology, Faculty of Biology, University of Gdańsk, Wita

Stwosza 59, 80-308 Gdańsk, Poland

${ }^{28}$ Croatian Society for Bird and Nature Protection, Zagreb, Croatia

${ }^{29}$ Sociedad Española de Ornitología (SEO/BirdLife), Madrid, Spain

${ }^{30}$ Faculty of Environmental Sciences, Czech University of Life Sciences, Praha Suchdol 129, CZ-165

21, Czechia

${ }^{31}$ National Academy of Science of Belarus, Independence Ave. 66, 220072, Minsk, Republic of Belarus

32 Département Études Aves-Natagora, Namur, Belgium

${ }^{33}$ Bulgarian Society for the Protection of Birds, PO Box 50, BG-1111 Sofia, Bulgaria.

${ }^{34}$ Hellenic Ornithological Society, Themistokleous str. 80, 10681, Athens, Greece

${ }^{35}$ SOS/BirdLife Slovakia, Bratislava, Slovakia

${ }^{36}$ Bird Protection and Study Society of Serbia, Vladike Ćirića 24/19, 21000 Novi Sad, Srbija

Makedonska 4, 11000 Beograd, Srbija

${ }^{37}$ Lithuanian Ornithological Society, Naugarduko 47-3, LT-03208 Vilnius, Lithuania

${ }^{38}$ Institute of Biology, University of Latvia, Salaspils, Latvia

${ }^{39}$ Swiss Ornithological Institute, Sempach, Switzerland

${ }^{40}$ BirdLife Österreich, Museumsplatz 1/10/8, 1070 Vienna / Austria

${ }^{41}$ Nase Ptice Ornithological Society, Sarajevo, Bosnia and Herzegovina 
$69 \quad{ }^{42}$ Macedonian Ecological Society, Boris Trajkovski st.7 No.9A, Skopje, Macedonia

$70{ }^{43}$ Natural History Museum of Montenegro, Trg Vojvode Bećir-bega Osmanagića 16, Podgorica,

71 Montenegro

$72 \quad{ }^{44}$ Dachverband Deutscher Avifaunisten e.V. (DDA), Federation of German Avifaunists, Münster,

73 Germany

$74 \quad{ }^{45}$ Istituto Superiore per la Protezione e la Ricerca Ambientale (ISPRA), Ozzano dell'Emilia, Italy

77 Corresponding author: Elie Gaget, University of Turku, Finland. E-mail: elie.gaget@gmail.com

78 Running head: Protected areas and distribution changes

79 Keywords: Colonization; Community adjustment; Community Temperature Index; Extinction; Range 80 shift; Wetlands 


\section{Abstract:}

Climate warming is driving changes in species distributions, although many species show a so-called climatic debt, where their range shifts lag behind the fast shift in temperature isoclines. Protected areas (PAs) may impact the rate of distribution changes both positively and negatively. At the cold edges of species distributions, PAs can facilitate species distribution changes by increasing the colonization required for distribution change. At the warm edges, PAs can mitigate the loss of species, by reducing the local extinction of vulnerable species. To assess the importance of PAs to affect species distribution change, we evaluated the changes in a non-breeding waterbird community as a response to temperature increase and PA status, using changes of species occurrence in the Western-Palearctic over 25 years (97 species, 7,071 sites, 39 countries, 19932017). We used a community temperature index (CTI) framework based on species thermal affinities to investigate the species turn-over induced by temperature increase. In addition, we measured whether the thermal community adjustment was led by cold-dwelling species extinction and/or warm-dwelling species colonization, by modelling the change in standard deviation of the CTI (CTI ${ }_{s d}$ ). Using linear mixed-effects models, we investigated whether communities within PAs had lower climatic debt and different patterns of community change regarding the local PA surface. Thanks to the combined use of the $\mathrm{CTI}$ and $\mathrm{CTI}_{s d}$, we found that communities inside PAs had more species, higher colonization, lower extinction and the climatic debt was $16 \%$ lower than outside PAs. The results suggest the importance of PAs to facilitate warm-dwelling species colonization and attenuate cold-dwelling species extinction. The community adjustment was however not sufficiently fast to keep pace with the strong temperature increase in central and northeastern Western-Palearctic regions. Our study underlines the potential of the combined $\mathrm{CTI}$ and $\mathrm{CTI}_{s d}$ metrics to understand the colonization-extinction patterns driven by climate warming. 


\section{Introduction}

105

106

107

108

109

110

111

Global warming is one of the major causes of biological changes among the growing cocktail of anthropic pressures on the natural world (Monastersky 2014). There are several studies documenting global species distribution shifts towards the poles (Parmesan \& Yohe 2003, Chen et al. 2011) which are driven by colonization at the leading distribution edge and extinction at the trailing edge (Thomas and Lennon 1999, Franco et al. 2006). However, distribution changes have mostly been insufficient to track the thermal isocline shifts, leading to climatic 'debt' in species distributions (Chen et al. 2011, Devictor et al. 2012). Furthermore, the pressures from climate change may be exacerbated by other factors interacting with colonization and extinction processes (Hill et al. 2001, Brook et al. 2008), like habitat fragmentation (Opdam and Wascher 2004, Hill et al. 2001) or land-use change (Auffret and Thomas 2019, Gaget et al. in press). However, some of these interactions may be positive, for example, protected areas may positively alter species ability to respond to climate change (Thomas et al. 2012).

Protected areas (hereafter, PAs) are expected to facilitate species distribution shifts in response to climate warming by reducing anthropic pressures on ecosystems (Monzón et al. 2011). PAs are one of the most efficient solutions to protect ecosystem of high biological importance (Godet and Devictor 2018). At the leading edge of species distributions, colonization may occur more likely in PAs (Hiley et al. 2013, Gillingham et al. 2015, Lehikoinen et al. 2019, Peach et al. 2019), particularly with large PA surface (Gaüzère et al. 2016), promoting range expansion (Thomas et al. 2012, PavónJordán et al. 2015). Conversely, species extinction at the trailing edge can be reduced within PAs (Gillingham et al. 2015, Lehikoinen et al. 2019, Peach et al. 2019). In view of these contrasting patterns, it is important to evaluate in a comprehensive framework the effects of PAs on species distributions throughout the overall community of species.

Temperature driven shifts in species distributions will reshuffle community structure, with colonization of warm-dwelling species and/or extinction of cold-dwelling species (Devictor et al. 
2008). Community adjustment to climate warming can be assessed with the intuitive community temperature index (hereafter, CTI), based on the average species thermal affinities in a community (Devictor et al. 2008). The CTI allows us to identify how local conditions such as site protection influence the community adjustment to warming (Gaüzère et al. 2016, Santangeli et al. 2017), and quantify any delay in tracking climate warming, namely the climatic debt (Devictor et al. 2012). In addition to the average community response measured with the $\mathrm{CTI}$, the variance of the response provides a complementary indicator with which to investigate the species colonization-extinction processes (Fig. 1, Gaüzère et al. 2019).

Here, we investigated the community adjustment of non-breeding waterbirds to climate warming throughout the Western-Palearctic over 25 years and whether the patterns of change differed within and outside of PAs. This region, extending from the Mediterranean biodiversity hotspot to the Arctic, faces substantial anthropic pressures (IPCC 2014, IPBES 2018a, 2018b). Despite great conservation efforts, wetlands in this region have suffered drastic damages (Dixon et al. 2016) and many waterbird populations have been declining for decades (Gardner \& Davidson 2011). Because of this, waterbirds have been targeted with a large-scale monitoring program, the International Waterbird Census (IWC, Delany 2010), which provides unique data to investigate the effectiveness of conservation strategies at continental scale (Pavón-Jordán et al. 2015, Amano et al. 2018). We expect that in response to climate warming, warm-dwelling waterbirds will colonize more in PAs and cold-dwelling species may be more resilient within PAs, as they usually contain good quality habitat (Lawson et al. 2014). Despite numerous studies on waterbird distribution changes in response to climate warming (e.g. Maclean et al. 2008, Lehikoinen et al. 2013, Pavón-Jordán et al. 2019), including conservation measures (Johnston et al. 2013, Pavón-Jordán et al. 2015, Gaget et al. 2018, 
We analyzed an extensive dataset on waterbird occurrence (97 species) across 39 countries $(7,071$

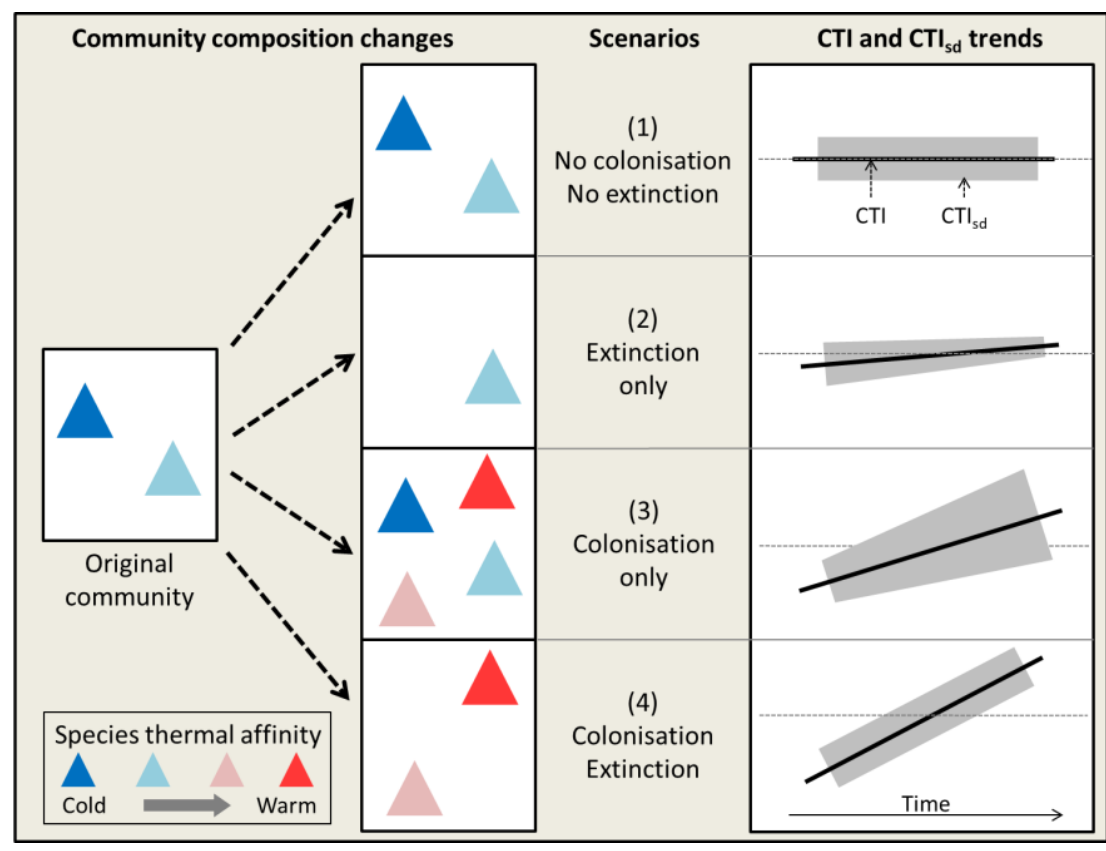

Figure 1: Schematic models of the four theoretical species colonization and/or extinction scenarios depending of their thermal affinities in response to climate warming and subsequent trends of community temperature index (CTI, i.e., thermal average) and $\mathrm{CTI}$ standard deviation $\left(\mathrm{CTI}_{s d}\right.$, i.e., thermal standard deviation) over time (see Gauzere et al. 2019). Species are represented by colored triangles: blue to red correspond to cold- and warm-dwelling species, respectively. The different scenarios are, (1) 'No colonization-No extinction' causes no CTI and $\mathrm{CTI}_{\text {sd }}$ changes; (2) 'Extinction only' causes CTI increase and $\mathrm{CTI}_{\text {sd }}$ decrease by the loss of cold-dwelling species; (3) 'Colonization only' causes $\mathrm{CTI}$ and $\mathrm{CTI}_{\text {sd }}$ increase by the gain of warm-dwelling species; (4) 'Colonization-Extinction' 
causes $\mathrm{CTI}$ increase by the species thermal turn-over, but no $\mathrm{CTI}_{\text {sd }}$ directional change. The code for simulations is in Appendix 1.

\section{Material and methods}

\section{Study area and waterbird monitoring}

173

174

175

We used International Waterbird Census (IWC) data from almost all of the Western-Palearctic (39 countries, Fig. 2, Appendix 2) from 1993-2017. The IWC monitors non-breeding waterbirds with a single count each year by ornithologists, professional or citizen scientists, in January and is coordinated by Wetlands International (www.wetlands.org, see Delany (2010) for the protocol). To ensure a long-term survey of community changes, we filtered the original data down to information from the 7,071 sites included in the study (Fig. 2) that each have at least five counts, with one count in each decade (1990s, 2000s and 2010s; $16.6 \pm 5.6$ counts per site) and at least two species per count ( $n=117,325$ counting events, Appendix 2). We included the 97 non-vagrant waterbird species overwintering in the Western-Palearctic (Appendix 3) listed in the African-Eurasian Migratory Waterbird Agreement (AEWA, http://www.unep-aewa.org).

\section{Protected areas and temperature data}

Site protection was reported for 3,374 sites from the World Database on Protected Areas (IUCN, UNEP-WCMC 2019), the Natura 2000 and the CDDA databases (www.eea.Europa.eu) (Fig. 2). Sites were considered as protected when their coordinates were included in the polygon of a protected area designated before 2017 . When polygon data were absent (12\% of the cases), a circular buffer was created based on the PA size reported in the World Database on Protected Areas (note that $100 \%$ concordance of site protection status was found by creating a circular area on the subset of PAs with polygons). The sites inside ( $n=3,374)$ and outside $(n=3,697)$ PAs had a similar number of 


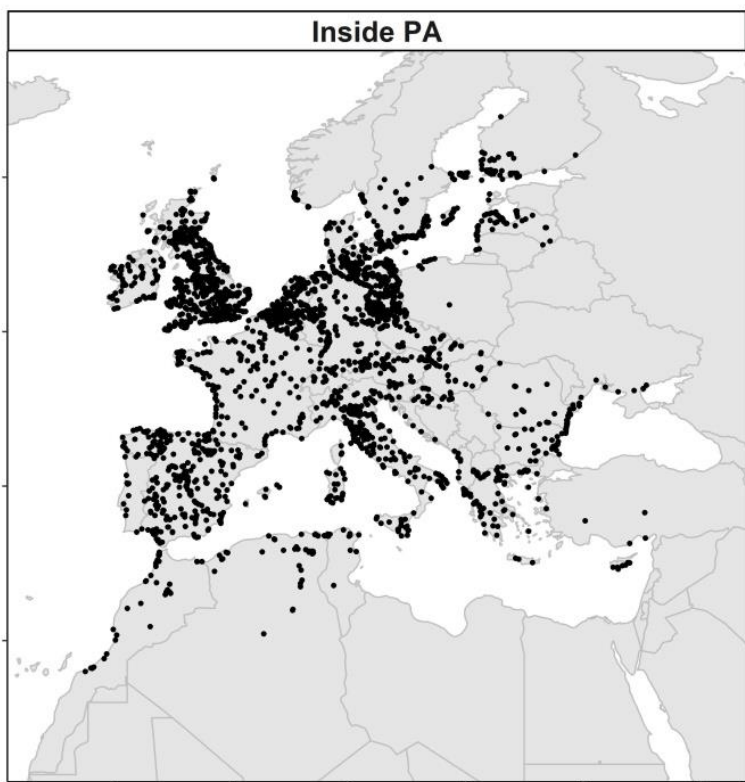

counts (in average ( $\pm S D$ ) $16.8 \pm 5.7$ and $16.4 \pm 5.7$, respectively) and a similar spatial distribution (in average $( \pm S D)$ Lat. $49.8 \pm 6.2$, Lon. $7.0 \pm 9.1$ and Lat. 50.3 \pm 6.1 , Lon. 5.2 \pm 9.0 , respectively, Fig. 2).

The HadCRUT4 dataset (Morice et al. 2012) that has a spatial resolution of $0.5^{\circ}$ was our source of temperature data. Yearly winter temperatures were computed each winter as the average of the mean monthly temperatures of November, December and January.

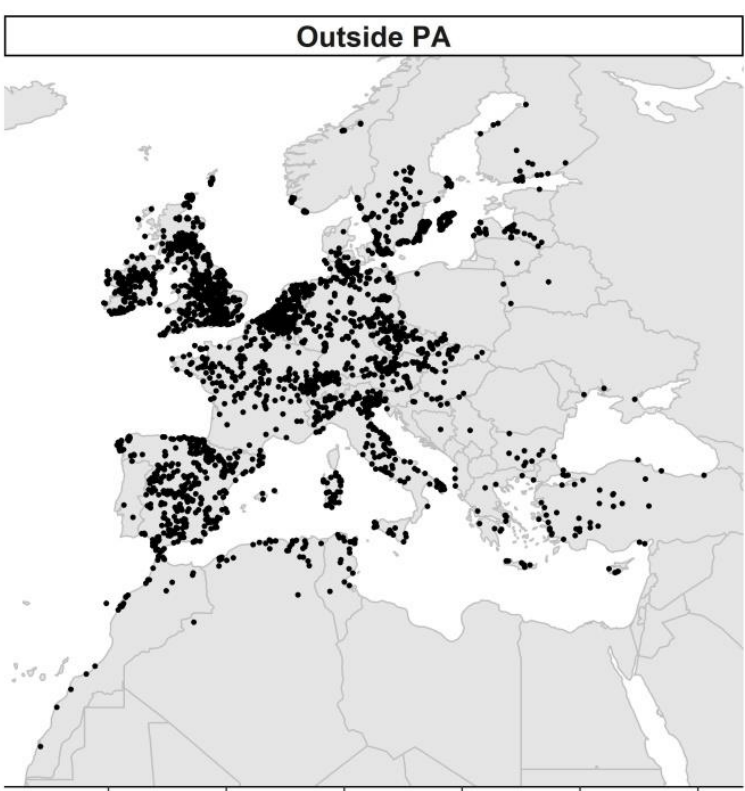

197

Figure 2: Map of the study area including 7,071 monitoring sites inside a protected area (PA, $n=$ $3,374)$ and outside $(n=3,697)$, in 39 Western-Palearctic countries.

\section{Community temperature indices}

Winter species temperature indices (STI) were computed as the species thermal affinity across the non-breeding species distribution following Gaget et al. (2018) (adapted for non-breeding waterbirds from Devictor et al. (2008)). The winter STI is the long-term average January temperature (WorldClim database, 1950-2000, http://worldclim.org/) experienced by the species across the nonbreeding (overwintering) distribution (extracted from www.birdlife.org 2015). Sub-species with 
distributions in Sub-Saharan African were removed to avoid an overestimation of the temperature experienced by the studied populations (Appendix 3).

The CTI and CTI standard deviation ( $\left.\mathrm{CTI}_{\mathrm{sd}}\right)$ were computed following Devictor et al. (2008) and Gaüzère et al. 2019 on species occurrence (presence/absence). The CTI is the average STI of the species present in the community per count event (see Appendix 4). The $\mathrm{CTI}_{\text {sd }}$ is the standard deviation of the species STI present in the community per count event, quantifying the STI heterogeneity in the community. Thus, the CTI increases over the years when there are more warmdwelling species or fewer cold-dwelling species. The $\mathrm{CTI}_{\text {sd }}$ increases over the years when the thermal affinities of the community become more heterogeneous (Fig. 1). Occurrence data were used instead of abundance data to make it easier to interpret the processes of colonization-extinction, but usually produce similar CTI trends (e.g. Devictor et al. 2008, Gaget et al. 2018).

\section{Data analysis}

Protected areas, $\mathrm{CTI}, \mathrm{CTI}_{s d}$ and climatic debt

Temporal changes of temperature, $\mathrm{CTI}$ and $\mathrm{CTI}_{\text {sd }}$ depending of the PA status were assessed with generalized linear mixed effects models (GLMM, Gaussian error distribution). The explanatory terms were the year (continuous variable from 1993-2017), the site protection status (Inside or Outside) and the interaction year $\times$ protected status. The site identity was added as a random effect on the intercept in the CTI and $\mathrm{CTI}_{s d}$ models. The spatial autocorrelation was taken into account by including the site geographical coordinates as an exponential spatial correlation structure in the model (Gaget et al. 2018). The linear model was:

$$
T_{i, j} \sim \mu+\text { year }_{i} \times P A_{j}+\text { site }_{j}+\varepsilon_{i, j}
$$


where $T_{i j}$ was the temperature, $\mathrm{CTI}$, or $\mathrm{CTI}_{s d}$, in year $i$ at site $j, \mu$ was the intercept, PA was the site protection status of site $j$, site was the random intercept per site that follows a Gaussian distribution with mean of zero and variance $\sigma^{2}$, and $\varepsilon$ was the residual variance for each observation under a Gaussian distribution and an exponential spatial correlation. In order to visually assess whether it was appropriate to model inter-annual changes as a linear effect, we generated and plotted mean annual values ( $\pm 95 \% \mathrm{Cl}$ ) by using the same model, but changing year to a categorical variable.

We looked for evidence of climatic debt accumulated by the waterbird communities by assessing the difference between the linear trends of temperature and CTI, following Devictor et al. (2008). First we investigated the latitudinal gradients in temperature and CTI with a GLMM (Gaussian error distribution), using the latitude as a fixed effect. The latitudinal gradient was converted to kilometres by dividing it by 111.128 , i.e., the average number of kilometres per 1 decimal degree temperature over the whole study area. Then the temporal temperature change $\left({ }^{\circ} \mathrm{C} \mathrm{yr}^{-1}\right)$ was converted to a velocity of temperature change in kilometres $\left(\mathrm{km} \mathrm{yr}^{-1}\right)$ by using the latitudinal temperature gradient $\left({ }^{\circ} \mathrm{C} \mathrm{km}^{-1}\right)$ from South to North of the study area. The same was done with the CTI. Lastly, the climatic debt was obtained by subtracting the velocity of the CTI change from the velocity of the temperature change over the study period.

In addition, we assessed the temporal trend of cold- and warm-dwelling species inside vs. outside

PAs. Species were classified in two categories as 'cold-dwelling' or 'warm-dwelling' following their STI in relation to the individual site, i.e., cooler or warmer than the mean CTI of the site's time series, respectively. Then, the number of cold and warm-species was summed per survey. We used these two simplified categories to control the accuracy of the community thermal changes assessed with

$250 \mathrm{CTI}$ and $\mathrm{CTI}_{s \mathrm{sd}}$. The temporal changes in number of cold- and warm-dwelling species were assessed using in a GLMM (Poisson error distribution) with fixed effects of year, the thermal-dwelling category (cold or warm), the site PA status (Inside or Outside) and their three-way interactions. The site identity was added as a random factor. The spatial autocorrelation was taken into account by 
including the site geographical coordinates as an exponential spatial correlation structure in the model.

We investigated whether the local $\mathrm{CTI}$, climatic debt and $\mathrm{CTI}_{\text {sd }}$ trends were correlated with the local PA surface. First, a moving-window approach was used to investigate the spatio-temporal changes of temperature, $\mathrm{CTI}$, climatic debt and $\mathrm{CTI}_{\text {sd }}$. The study area was divided in 1,032 cells of $5^{\circ} \times 5^{\circ}$ resolution (c. $500 \times 500 \mathrm{~km}$ ) spaced from each other by one latitudinal or longitudinal degree. We performed one GLMM per cell per response variable (temperature, $\mathrm{CTI}$ and $\mathrm{CTI}_{\mathrm{sd}}$ ), to investigated their change over years using the same model structure as before. Temperature, CTI and climatic debt spatio-temporal changes were given in $\mathrm{km} \mathrm{yr}^{-1}$, and in ${ }^{\circ} \mathrm{C} \mathrm{yr}^{-1}$ for the $\mathrm{CTI}_{\mathrm{sd}}$. Note that each cell included both protected and not protected sites and at least 15 sites (mean of 175 sites), to avoid cells with a small number of sites at the edge of the study area.

Then, we investigated the relationship between the PA surface per cell and the CTI spatial shift, $\mathrm{CTI}_{\text {sd }}$ and climatic debt trends, estimated from the models above. One generalised linear model (GLM, Gaussian error distribution) was used per response variable with fixed effects the PA surface (sum of the PA surfaces per cell, log transformation assuming a non-linear relation) and the temperature spatial shift plus their interaction to control for the climate warming pressure. To investigate the geographical PA surface repartition in the Western-Palearctic, we also assessed in a GLM whether PA surface increased with latitude, longitude and their interaction.

274 All the statistical analyses were performed with R 3.4.3 (R Core Team 2017), using the 'glmmTMB' package (Magnusson et al. 2017) for the GLMM and GLM. 


\section{Results}

Protected areas, CTI, CTI sd and climatic debt

The temperature increased by $0.04^{\circ} \mathrm{C}$ per year $(\mathrm{P}<0.001)$ without significant difference between inside and outside PA ( $P=0.2$, Table 1, Fig. 3a). The CTI increased faster inside PAs than outside,

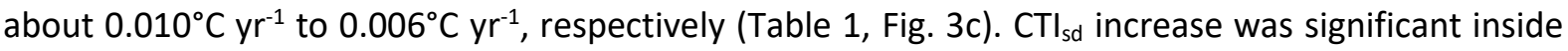
PAs, but not significant outside PAs (Table 1, Fig. 3d). Therefore, within PAs, the results matched scenario 3 (Fig. 1; colonization only), whereas outside PAs the results matched scenario 4 (Fig. 1; colonization and extinction).

Temporal changes in CTI lagged behind changes in temperature. The temperature latitudinal gradient was about $-0.38^{\circ} \mathrm{C}$ per decimal degree $(\mathrm{SE}=0.005, \mathrm{Z}=-78.75, \mathrm{P}<0.001)$ and $-0.31^{\circ} \mathrm{C}(\mathrm{SE}=$ $0.004, \mathrm{Z}=-69.56, \mathrm{P}<0.001)$ for the CTI. The temperature increase was equivalent to a latitudinal shift of $11.4 \mathrm{~km} \mathrm{yr}^{-1}$ (285 $\mathrm{km}$ in 25 years). The temporal CTI trend was equivalent to a shift $43 \%$ larger inside PAs than outside, with about $3.5 \mathrm{~km} \mathrm{yr}^{-1}$ inside the PAs (87 km over 25 years) and $2.0 \mathrm{~km} \mathrm{yr}^{-1}$ and $9.4 \mathrm{~km} \mathrm{yr}^{-1}$ outside (198 km and $235 \mathrm{~km}$ over 25 years, respectively).

The number of cold- and warm-dwelling species both increased significantly over the study period, but the trends and average numbers of species were significantly greater inside PAs (Table 1, Fig. 3b). Warm-dwelling species were more numerous and their number increased faster than the colddwelling species (Table 1). Inside PAs, the warm-dwelling species increased also faster than the colddwelling species (Table 1). This suggests that, both inside and outside PAs fit between scenarios 3 and 4 - with more colonization than extinction. 
(a)

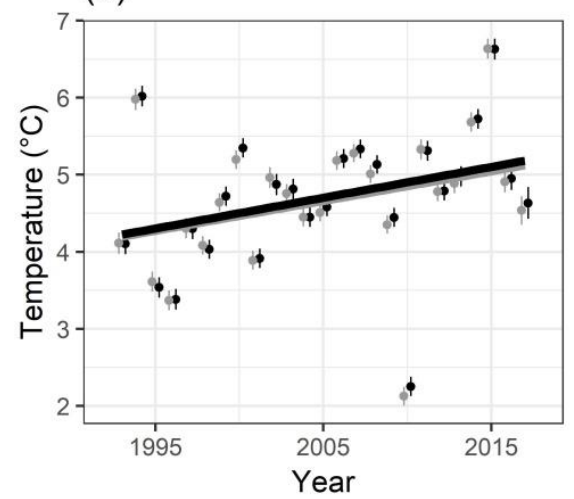

(c)

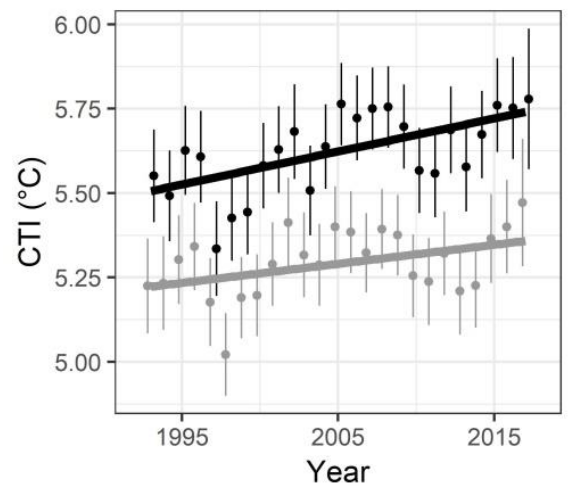

(b)

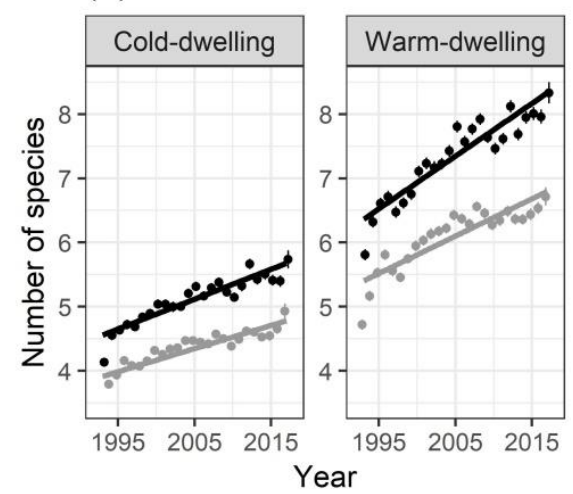

(d)

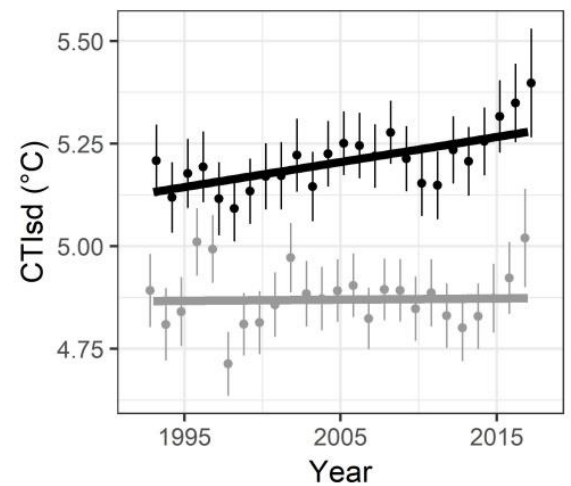

298

299

300

301

302

303

304

305

306

Figure 3: Temporal trends inside PA (black) and outside PA (grey) of the (a) temperature, (b) number of cold- and warm-dwelling species, (c) community temperature index (CTI) and (d) standard deviation of the $\mathrm{CTI}\left(\mathrm{CTI}_{\mathrm{sd}}\right)$. Mean $( \pm 95 \% \mathrm{Cl})$ are represented by points.

Table 1: Temporal trends of the temperatures, community temperature index (CTI) and standard deviation of the $\mathrm{CTI}\left(\mathrm{CTI}_{\mathrm{sd}}\right)$ and number of cold- and warm-dwelling species regarding the protected area (PA) site status. Base line is sites outside PA and cold-dwelling species. Years were standardized to zero mean (std.) in the thermal-dwellers model and interactions are notified by ' $:$ '.

\begin{tabular}{|c|c|c|c|c|c|}
\hline Variable & Parameter & Coefficient & SE & Z-value & P-value \\
\hline \multirow{4}{*}{ Temperature } & Intercept & -72.660 & 1.364 & -53.290 & $<0.001$ \\
\hline & Year & 0.039 & 0.001 & 56.750 & $<0.001$ \\
\hline & PA & 2.704 & 1.957 & 1.380 & 0.167 \\
\hline & Year:PA & 0.001 & 0.001 & 1.400 & 0.160 \\
\hline \multirow{4}{*}{ CTI } & Intercept & -6.030 & 1.696 & -3.554 & $<0.001$ \\
\hline & Year & 0.006 & 0.001 & 6.676 & $<0.001$ \\
\hline & PA & 7.972 & 2.435 & 3.274 & $<0.001$ \\
\hline & Year:PA & 0.004 & 0.001 & 3.412 & $<0.001$ \\
\hline \multirow{3}{*}{$\mathrm{CTI}_{\mathrm{sd}}$} & Intercept & 4.294 & 1.602 & 2.680 & 0.007 \\
\hline & Year & 0.000 & 0.001 & 0.360 & 0.719 \\
\hline & PA & 11.310 & 2.300 & 4.920 & $<0.001$ \\
\hline
\end{tabular}




\begin{tabular}{clrrrr}
\hline & Year:PA & 0.006 & 0.001 & 5.066 & $<0.001$ \\
\hline & Intercept & 1.466 & 0.012 & 125.070 & $<0.001$ \\
& Year(std.) & 0.057 & 0.002 & 33.560 & $<0.001$ \\
& PA & 0.163 & 0.017 & 9.600 & $<0.001$ \\
Cold- and warm- & Dweller & 0.338 & 0.002 & 154.600 & $<0.001$ \\
dwellers & Year(std.):PA & 0.005 & 0.002 & 2.360 & 0.018 \\
& Year(std.):Dweller & 0.008 & 0.002 & 3.820 & $<0.001$ \\
& PA:Dwellers & 0.022 & 0.003 & 7.360 & $<0.001$ \\
& Year(std.):PA:Dweller & 0.006 & 0.003 & 1.960 & 0.049 \\
\hline
\end{tabular}

The temperature increased significantly in $80 \%$ of the study area, with the exception of the northern half of the Iberian Peninsula (Fig. 4A). The CTI significantly increased in $37 \%$ of the cells $(384 / 1,032)$, mostly from South Balkans to West France and around the Baltic Sea (Fig. 4B). Consequently, there was climatic debt in $66 \%$ of the area, mostly in the northern half of Europe (Fig. 4C). Lastly, the $\mathrm{CTI}_{\text {sd }}$ trend was significantly positive in $39 \%$ of the cells, mainly in the East and the South, but also around the Baltic Sea (Fig. 4D).

The CTI spatial shift increased with PA surface and temperature spatial shift $(P \leq 0.001)$ but without a significant interaction (Table 2). Consequently, the climatic debts accumulated were smaller where there was more PA surface and greater where the temperature spatial shift was faster $(P \leq 0.001)$ (Table 2). The temporal $\mathrm{CTI}_{\text {sd }}$ trends did not change with PA surface $(P=0.3)$, but increased less where the temperature spatial shift was faster $(\mathrm{P}<0.001$, Table 2$)$. However, the $\mathrm{CTI}_{\text {sd }}$ trends decreased when both PA surface and temperature spatial shift increased as demonstrated by a negative interaction between temperature spatial shift and PA surface (Table 2). The PA surface areas were greater in southwest and northeast, as the PA surface decreased with the longitude $(\beta=-$ $0.266, P<0.001)$ but not with the latitude $(\beta=-0.067, P<0.14)$, with a positive and significant interaction $(\beta=0.274, P<0.001$, Appendix 5). 


\section{A) Temperature}

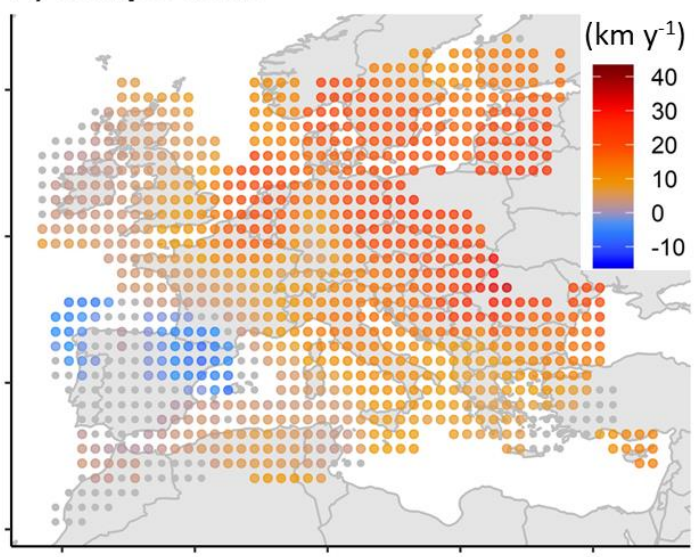

\section{C) Climatic debt}

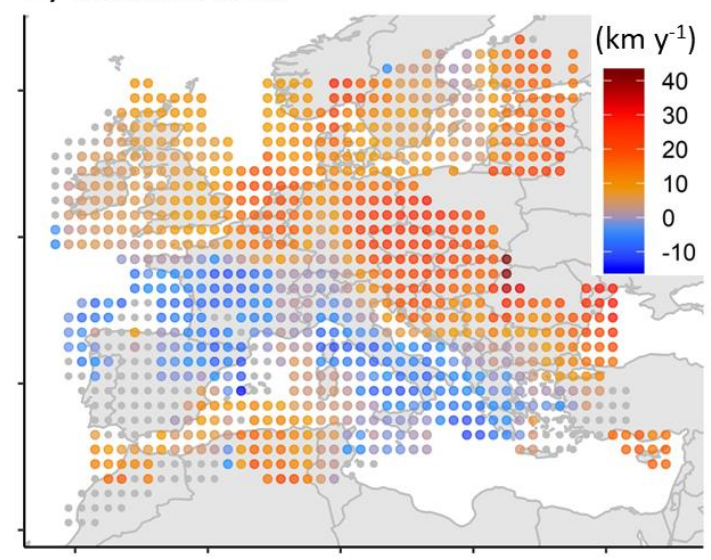

\section{B) Community temperature index (CTI)}

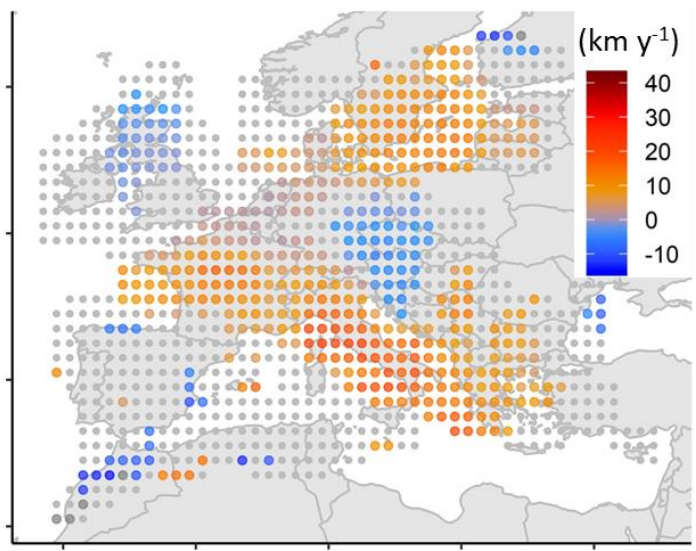

D) Thermal heterogeneity $\left(\mathrm{CTI}_{\text {sd }}\right)$

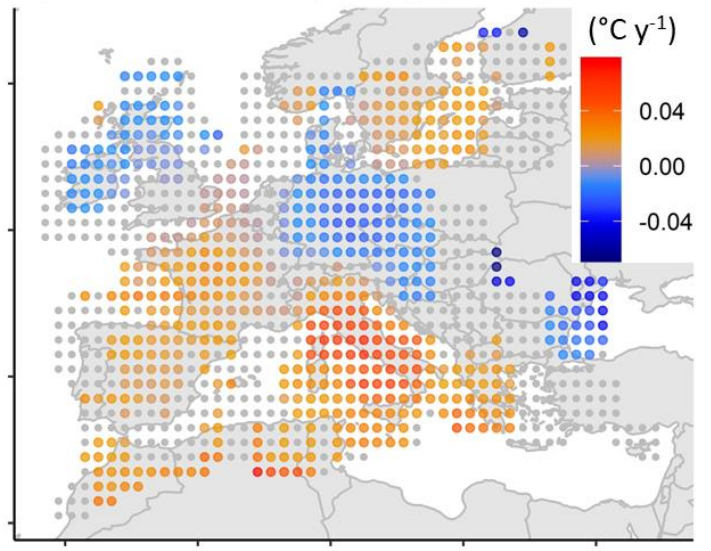

Figure 4: Spatio-temporal trends from 1993-2017 of (A) temperature, (B) community temperature

located at the centre of the corresponding cell $\left(5^{\circ} \times 5^{\circ}\right.$ resolution). Coloured points denote a

intensity (not significant trend in grey).

Table 2: Spatial effect of protected area surface (log transformed) and interaction with the temperature spatial shift on the $\mathrm{CTI}$ spatial shift, climatic debt and $\mathrm{CTI}_{\text {sd, }}$, per cell of $5^{\circ} \times 5^{\circ}$. Interacting effects denoted by ' $:$ '.

\begin{tabular}{clrlrr}
\hline Variable & \multicolumn{1}{c}{ Parameter } & Coefficient & SE & Z-value & P-value \\
\hline \multirow{2}{*}{ CTI spatial } & Intercept & 3.086 & 0.203 & 15.220 & $<0.001$ \\
shift & PA surface & 0.666 & 0.204 & 3.268 & 0.001 \\
& Temperature spatial shift & 1.074 & 0.205 & 5.252 & $<0.001$
\end{tabular}




\begin{tabular}{clrrrr} 
& PA surface : Temperature & & & & \\
& spatial shift & 0.130 & 0.250 & 0.517 & 0.605 \\
\hline \multirow{2}{*}{$\begin{array}{c}\text { Climatic } \\
\text { debt }\end{array}$} & PA surface & 168.688 & 5.069 & 33.280 & $<0.001$ \\
& Temperature spatial shift & -16.658 & 5.094 & -3.270 & 0.001 \\
& PA surface : Temperature & 167.104 & 5.112 & 32.690 & $<0.001$ \\
& spatial shift & & & & \\
& Intercept & -3.233 & 6.256 & -0.520 & 0.605 \\
\hline \multirow{2}{*}{$\mathrm{CTI}_{\text {sd }}$} & PA surface & 0.007 & 0.001 & 13.220 & $<0.001$ \\
& Temperature spatial shift & 0.001 & 0.001 & 1.111 & 0.267 \\
& PA surface : Temperature & -0.005 & 0.001 & -9.822 & $<0.001$ \\
& spatial shift & & & & \\
& & -0.002 & 0.001 & -2.799 & 0.005 \\
\hline
\end{tabular}

\section{Discussion}

This study represents one of the first empirical and international assessments addressing difference in community changes in response to climate warming within PAs on a continental scale. We found that the CTI faster increase inside PAs compared to outside areas was driven mainly by colonization from warm-dwelling species, which is consistent with other studies on birds and other taxonomic groups (Thomas et al. 2012, Gillingham et al. 2015). Indeed, when looking at finer spatial scale, the $\mathrm{CTI}$ increase was more positive where PA surfaces were larger, suggesting a positive relationship of PA coverage on community thermal changes (Gaüzère et al. 2016).

347 Overall, we find that non-breeding waterbirds in the Western-Palearctic show a climatic debt, but this debt is $16 \%$ lower inside PAs. Communities inside PAs had higher colonization, lower extinction and lower climatic debt. Moreover, PAs supported higher waterbird species richness, which is consistent with the PA designation on wetlands of high biological importance, e.g. by the Ramsar

351 Convention and the European Union's Nature Directives. Therefore PAs are not only important to reduce the direct anthropic pressures (Godet $\&$ Devictor 2018) but also are associated with reduced 
climatic debt. Such conservation benefit was expected by international conservation policies

354 (Trouwborst 2009, 2011, 2012), which use PAs and species protection status as the main conservation measures to buffer the negative impacts of climate change, in order to reduce ecosystem pressures and promote species adaptation to climate change (Trouwborst 2011, 2012).

The Western-Palearctic falls under several of these international conventions, such as the Ramsar, species by the Bern Convention (19.IX.1979) and the Birds Directive (79/409/EEC) in 1979. After that, a fast population recovery occurred notably by a northward expansion (Hiley et al. 2013, Ławicki 2014, Marion \& Bergerot 2018).

Species richness of non-breeding waterbird increased over the study area, particularly inside PAs, in line with recent general positive trends of Western-Palearctic waterbird populations (Amano et al. 2018). Furthermore, inside - but not outside - PAs the variation in CTI (CTI $\left.{ }_{s d}\right)$ increased over time, and we find a general increase in CTI of both cold- and warm-dwelling species over time. These findings suggest that inside PAs, species with high thermal affinity colonized the community, but at the same time species with low thermal affinity were less likely to be locally extinct. In other words, despite the proximity with the thermal niche edge. 
The intensity of the winter temperature warming increased over a southwest-northeast gradient, driving the community adjustment through a similar gradient of intensity, although not perfectly (Fig. 4). The thermal isocline shift towards the northeast is related to the continental shape and the oceanic influence of the Gulf Stream (IPCC 2014). Interestingly, the non-significant temperature and CTI trends in the southwest of the Western-Palearctic resulted in negligible climatic debts. Conversely, the climatic debt increased in the northeastern countries where strong temperature warming occurred (Fig. 4), which non-breeding waterbirds were not able to fully track.

Temperature was likely not the only aspect of the physical environment that constrained species' distributions. The local pattern of CTI changes contrasted with the expected relative increase of warm-dwelling species. While several other factors are likely to have affected species' distributions, the CTI focuses on species assemblage changes in response to temperature changes, but its trend can also be affected by other drivers of population change (Bowler \& Böhning-Gaese 2017). For example, in the UK, despite a species-specific west-east waterbird redistribution (Austin \& Rehfisch 2005), the CTI changes were likely altered by the recent increase of geese and the decrease of waders (Frost et al. 2019), which have low and high STIs, respectively (Appendix 3). Consequently, the subsequent community reshuffling may jeopardize the detection of a community thermal adjustment, if it exists (Bowler \& Böhning-Gaese 2017). Similarly, the absence of CTI increase in Central Europe and in the Netherlands despite the temperature increase should encourage speciesspecific investigations (e.g. Pavón-Jordán et al. 2015). Such unexpected population changes, under the hypothesis of a community adjustment to climate warming, increase the theoretical mismatch between community and temperature changes (Kerbiriou et al. 2009, Galewski and Devictor 2016).

Although milder climate conditions reduce ice and snow in the northern regions and enhance northward range expansion (Brommer 2008, Schummer et al. 2010), the community adjustment to climate warming was not particularly strong in northern Europe (Fig. 4). This may be the result of average temperatures not accurately reflecting the thermal conditions that affect species' 
distribution. For example, in the northern regions, severe cold spells may cause potential large mortality, this limiting species distribution changes (Gunnarsson et al. 2012).

Considering the strong waterbird distribution change in northern Europe (Brommer 2008, Lehikoinen et al. 2013), the lack of CTI increase also suggests some limits of the CTI framework. The CTI measures changes of species assemblages (Devictor et al. 2008) and could be sensitive to the number of species already present in the community. Indeed, when there are few species at the beginning of the monitoring, because of ice cover for example, the CTI trend should be more sensitive to the species arrivals. We acknowledge that we didn't tack into account for this potential uncertainty. Consequently, our ability to measure species distribution change is challenged in these ice-dominated regions, where the community adjustment to climate warming is likely underestimated (Fox et al. 2019).

\section{Perspectives for research and conservation}

Indicators are essential tools to synthesize population dynamics and inform public policies (Tittensor et al. 2014). The CTI is an intuitive indicator with which to measure and communicate the impact of climate warming on communities (Devictor et al. 2012, Gaüzère et al. 2019). Here, we go one step further and used the $\mathrm{CTI}_{s d}$ to identify the colonization-extinction patterns in response to climate warming (see also Appendix 1). With these simple indicators, we identified that the community adjustment to temperature was mainly due to colonization by the warm-dwelling species inside PAs, while outside PAs the extinction of the most cold-dwelling species was nearly equivalent to the colonization by warm-dwelling species (Fig. 3d). 
areas (Delany 2010). However, we acknowledge that PAs were not randomly distributed (Fig. 2), and that such non-randomness could induce spatial aggregation between PA density and CTI changes. Nevertheless, when looking at the spatio-temporal changes (Fig. 4), spatial aggregation was moderate. In particular, the CTI trends were heterogeneous even between areas with high PA density (Fig. 2), e.g. in the Netherlands or southern UK. More emphasis should be given to investigate how PA characteristics, e.g. management plans, influence at a local scale community adjustment to climate warming (Monzón et al. 2011).

Non-breeding waterbirds have high capacity to respond to climate warming by a distribution change (Maclean et al. 2008, Lehikoinen et al. 2013, Pavón-Jordán et al. 2019) even more than other groups of birds (Brommer 2008). Our study reveals a faster average distribution shift, 2.0 to $3.5 \mathrm{~km} \mathrm{yr}^{-1}$, in comparison to the European common breeding birds (2.1 $\mathrm{km} \mathrm{yr}^{-1}$, Devictor et al. 2012) and other taxa (1.8 $\mathrm{km} \mathrm{yr}^{-1}$, Chen et al. 2011). Indeed, most of the Western-Palearctic waterbirds are migratory, spending energy and facing multiple threats during migration. Shortening their migration routes, by overwintering at more northern latitudes, could be advantageous, by decreasing the migration cost and benefits their fitness (Gilroy 2017, Reneerkens et al. 2019).

These rapid distributional changes that we found bring into question the future effectiveness of the PA networks, because of the locations of these sites potentially do not match the future distributions of waterbird species (Araújo et al. 2004). In the Western-Palearctic, the PA network covers $45 \%$ of the inland wetlands (Bastin et al. 2019) and even if the number of PAs increases in the northeast, the network still does not cover all the wetlands important for waterbird conservation (Pavón-Jordán et al. 2015, Pavón-Jordán in Rev.). In the future, PAs can maintain their conservation value if the extinction of conservation concern species is compensated by the colonization of other 447 species of conservation concern (Hole et al. 2009, Johnston et al. 2013). From that perspective, our results are encouraging, as they indicate the PAs would still remain important for waterbird conservation in the future, since waterbird colonization was greater, and extinction lower, inside a 
bioRxiv preprint doi: https://doi.org/10.1101/2021.04.26.441480; this version posted April 27, 2021. The copyright holder for this preprint (which was not certified by peer review) is the author/funder. All rights reserved. No reuse allowed without permission.

450 PA compared to outside. However, more studies are needed to understand the mechanisms by

451 which PAs have buffered against climate change, and to evaluate the current and future

452 completeness of the PA network particularly for conservation concern species (Pavón-Jordán et al.

453 2015). 
455

456

457

458

459

460

461

462

463

464

465

466

467

468

469

470

471

472

473

474

475

476

477

478

479

480

481

482

483

484

485

486

487

488

489

490

491

We acknowledge the thousands of volunteers and professionals involved in the International Waterbird Census, making this research possible. This research was funded through the 2017-2018 Belmont Forum and BiodivERsA joint call for research proposals, under the BiodivScen ERA-Net COFUND programme, with the following funding organizations: the Academy of Finland (Univ. Turku: 326327, Univ. Helsinki: 326338), the Swedish Research Council (Swedish Univ. Agric. Sci: 201802440, Lund Univ.: 2018-02441), the Research Council of Norway (Norwegian Instit. for Nature Res., 295767), the National Science Foundation (Cornell Univ., ICER-1927646) and we also acknowledge the Swedish Environmental Protection Agency.

\section{References}

Amano, T., et. al. (2018). Successful conservation of global waterbird populations depends on effective governance. Nature, 553(7687), 199.

Araújo, M. B., Cabeza, M., Thuiller, W., Hannah, L., \& Williams, P. H. (2004). Would climate change drive species out of reserves? An assessment of existing reserve-selection methods. Global change biology, 10(9), 1618-1626.

Auffret, A. G., \& Thomas, C. D. (2019). Synergistic and antagonistic effects of land use and non-native species on community responses to climate change. Global change biology.

Austin, G. E., \& Rehfisch, M. M. (2005). Shifting nonbreeding distributions of migratory fauna in relation to climatic change. Global Change Biology, 11(1), 31-38.

Bastin, L., Gorelick, N., Saura, S., Bertzky, B., Dubois, G., Fortin, M. J., \& Pekel, J. F. (2019). Inland surface waters in protected areas globally: Current coverage and 30-year trends. PloS one, 14(1), e0210496.

Berteaux, D., Ricard, M., St-Laurent, M. H., Casajus, N., Périé, C., Beauregard, F., \& de Blois, S. (2018). Northern protected areas will become important refuges for biodiversity tracking suitable climates. Scientific reports, 8(1), 4623.

BirdLife International and Handbook of the Birds of the World (2018) Bird species distribution maps of the world. Version 2018.1. Available at http://datazone.birdlife.org/species/requestdis

Bowler, D., \& Böhning-Gaese, K. (2017). Improving the community-temperature index as a climate change indicator. PloS one, 12(9), e0184275.

Brommer, J. E. (2008). Extent of recent polewards range margin shifts in Finnish birds depends on their body mass and feeding ecology. Ornis Fennica, 85(4), 109-17.

Brook, B. W., Sodhi, N. S., \& Bradshaw, C. J. (2008). Synergies among extinction drivers under global change. Trends in ecology \& evolution, 23(8), 453-460.

Chen, I. C., Hill, J. K., Ohlemüller, R., Roy, D. B., \& Thomas, C. D. (2011). Rapid range shifts of species associated with high levels of climate warming. Science, 333(6045), 1024-1026.

Delany S. 2010. Guidance on Waterbird Monitoring Methodology: Field Protocol for Waterbird Counting (Wetlands International). 
Devictor, V., Julliard, R., Couvet, D., \& Jiguet, F. (2008). Birds are tracking climate warming, but not fast enough. Proceedings of the Royal Society B: Biological Sciences, 275(1652), 2743-2748.

Devictor, V., et. al. (2012). Differences in the climatic debts of birds and butterflies at a continental scale. Nature climate change, 2(2), 121.

Dixon, M. J. R., Loh, J., Davidson, N. C., Beltrame, C., Freeman, R., \& Walpole, M. (2016). Tracking global change in ecosystem area: the Wetland Extent Trends index. Biological Conservation, 193, 2735.

Finlayson, C. M., et al. (2017). Policy considerations for managing wetlands under a changing climate. Marine and Freshwater Research, 68(10), 1803-1815.

Fox, A. D., Nielsen, R. D., \& Petersen, I. K. (2019). Climate-change not only threatens bird populations but also challenges our ability to monitor them. Ibis, 161(2), 467-474.

Franco, A. M., et. al. (2006). Impacts of climate warming and habitat loss on extinctions at species' low-latitude range boundaries. Global Change Biology, 12(8), 1545-1553.

Frost, T. et al. (2019). Population estimates of wintering waterbirds in Great Britain. British Birds, 112, 130-145.

Gaget, E., Galewski, T., Jiguet, F., Guelmami, A., Perennou, C., Beltrame, C. \& Le Viol I. (2019) Antagonistic effect of natural habitat conversion on community adjustment to climate warming in non-breeding waterbirds. Conservation Biology, in press, DOI: 10.1111/cobi.13453

Gaget, E., Galewski, T., Jiguet, F., \& Le Viol, I. (2018). Waterbird communities adjust to climate warming according to conservation policy and species protection status. Biological conservation, $227,205-212$.

Galewski T, Devictor V (2016) When Common Birds Became Rare: Historical Records Shed Light on Long-Term Responses of Bird Communities to Global Change in the Largest Wetland of France. PLOS ONE, 11, e0165542.

Gamero, A., et. al. (2017). Tracking progress toward EU biodiversity strategy targets: EU policy effects in preserving its common farmland birds. Conservation Letters, 10(4), 395-402.

Gardner, R. C., \& Davidson, N. C. (2011). The ramsar convention. In Wetlands (pp. 189-203). Springer, Dordrecht.

Gaüzère, P., Doulcier, G., Devictor, V., \& Kéfi, S. (2019). A framework for estimating species-specific contributions to community indicators. Ecological indicators, 99, 74-82.

Gaüzère, P., Jiguet, F., \& Devictor, V. (2016). Can protected areas mitigate the impacts of climate change on bird's species and communities?. Diversity and Distributions, 22(6), 625-637.

Gilroy, J. J., Gill, J. A., Butchart, S. H., Jones, V. R., \& Franco, A. M. (2016). Migratory diversity predicts population declines in birds. Ecology letters, 19(3), 308-317.

Gillingham, P. K., et. al. (2015). The effectiveness of protected areas in the conservation of species with changing geographical ranges. Biological Journal of the Linnean Society, 115(3), 707-717.

Godet, L., \& Devictor, V. (2018). What conservation does. Trends in ecology \& evolution, 33(10), 720730.

Gunnarsson, G., Waldenström, J., \& Fransson, T. (2012). Direct and indirect effects of winter harshness on the survival of Mallards Anas platyrhynchos in northwest Europe. Ibis, 154(2), 307-317.

Hiley, J. R., Bradbury, R. B., Holling, M., \& Thomas, C. D. (2013). Protected areas act as establishment centres for species colonizing the UK. Proceedings of the Royal Society B: Biological Sciences, 280(1760), 20122310. 
Hill, J. K., Collingham, Y. C., Thomas, C. D., Blakeley, D. S., Fox, R., Moss, D., \& Huntley, B. (2001). Impacts of landscape structure on butterfly range expansion. Ecology Letters, 4(4), 313-321.

Hole, D. G., et al. (2009). Projected impacts of climate change on a continent-wide protected area network. Ecology letters, 12(5), 420-431.

IPBES (2018a): The IPBES regional assessment report on biodiversity and ecosystem services for Africa. Archer, E. Dziba, L., Mulongoy, K. J., Maoela, M. A., and Walters, M. (eds.). Secretariat of the Intergovernmental Science-Policy Platform on Biodiversity and Ecosystem Services, Bonn, Germany. 492 pages. http://doi.org/10.5281/zenodo.3236178

IPBES (2018b): Summary for policymakers of the regional assessment report on biodiversity and ecosystem services for Europe and Central Asia of the Intergovernmental Science-Policy Platform on Biodiversity and Ecosystem Services. M. Fischer, M. Rounsevell, A. Torre-Marin Rando, A. Mader, A. Church, M. Elbakidze, V. Elias, T. Hahn, P.A. Harrison, J. Hauck, B. Martín-López, I. Ring, C. Sandström, I. Sousa Pinto, P. Visconti, N.E. Zimmermann and M. Christie (eds.). IPBES secretariat, Bonn, Germany. 48 pages https://doi.org/10.5281/zenodo.3237428

IPCC (2014). Climate change 2014: synthesis report. Contribution of Working Groups I. II and III to the fifth assessment report of the Intergovernmental Panel on Climate Change, 151.

Johnston, A., et. al. (2013). Observed and predicted effects of climate change on species abundance in protected areas. Nature Climate Change, 3(12), 1055.

Kerbiriou C, Le Viol I, Jiguet F, Devictor V (2009) More species, fewer specialists: 100 years of changes in community composition in an island biogeographical study. Diversity and Distributions, 15, 641-648.

Ławicki, Ł. (2014). The Great White Egret in Europe: population increase and range expansion since 1980. British Birds, 107(1), 8-25.

Lawson, C. R., Bennie, J. J., Thomas, C. D., Hodgson, J. A., \& Wilson, R. J. (2014). Active management of protected areas enhances metapopulation expansion under climate change. Conservation Letters, 7(2), 111-118.

Lehikoinen, A., et. al. (2013). Rapid climate driven shifts in wintering distributions of three common waterbird species. Global change biology, 19(7), 2071-2081.

Lehikoinen, P., Santangeli, A., Jaatinen, K., Rajasärkkä, A., \& Lehikoinen, A. (2019). Protected areas act as a buffer against detrimental effects of climate change-Evidence from large-scale, long-term abundance data. Global change biology, 25(1), 304-313.

Maclean, I. M., et. al. (2008). Climate change causes rapid changes in the distribution and site abundance of birds in winter. Global Change Biology, 14(11), 2489-2500.

Magnusson A., Skaug H., Nielsen A., Berg C., Kristensen K., Maechler M., van Bentham K., Bolker B. \& Brooks M. M. 2017. Package 'glmmTMB'.

Marion, L., \& Bergerot, B. (2018). Northern range shift may be due to increased competition induced by protection of species rather than to climate change alone. Ecology and evolution, 8(16), 83648379.

Monastersky, R. (2014). Biodiversity: Life-a status report. Nature News, 516(7530), 158.

Monzón, J., Moyer-Horner, L., \& Palamar, M. B. (2011). Climate change and species range dynamics in protected areas. Bioscience, 61(10), 752-761.

Morice, C. P., Kennedy, J. J., Rayner, N. A., \& Jones, P. D. (2012). Quantifying uncertainties in global and regional temperature change using an ensemble of observational estimates: The HadCRUT4 data set. Journal of Geophysical Research: Atmospheres, 117(D8). 
Opdam, P., \& Wascher, D. (2004). Climate change meets habitat fragmentation: linking landscape and biogeographical scale levels in research and conservation. Biological conservation, 117(3), 285297.

Parmesan, C., \& Yohe, G. (2003). A globally coherent fingerprint of climate change impacts across natural systems. Nature, 421(6918), 37.

Pavón-Jordán, D., et. al. (2019). Habitat-and species-mediated short-and long-term distributional changes in waterbird abundance linked to variation in European winter weather. Diversity and Distributions, 25(2), 225-239.

Pavón-Jordán, D., Fox, A. D., Clausen, P., Dagys, M., Deceuninck, B., Devos, K., ... \& Langendoen, T. (2015). Climate-driven changes in winter abundance of a migratory waterbird in relation to EU protected areas. Diversity and Distributions, 21(5), 571-582.

Pavón-Jordán et al. Towards a more robust network of protected areas for migratory birds associated with wetlands across Europe and North Africa under climate change. Under revision in Biological Conservation.

Peach, M. A., Cohen, J. B., Frair, J. L., Zuckerberg, B., Sullivan, P., Porter, W. F., \& Lang, C. (2019). Value of protected areas to avian persistence across 20 years of climate and land-use change. Conservation Biology, 33(2), 423-433.

R. C. Team (2017). R: A language and environment for statistical computing. R Foundation for Statistical Computing (Versión 3.4. 3).

Reneerkens, J., et al. (2019). Low fitness at low latitudes: wintering in the tropics increases migratory delays and mortality rates in an arctic-breeding shorebird. Journal of Animal Ecology.

Santangeli, A., \& Lehikoinen, A. (2017). Are winter and breeding bird communities able to track rapid climate change? Lessons from the high North. Diversity and Distributions, 23(3), 308-316.

Schummer, M. L., Kaminski, R. M., Raedeke, A. H., \& Graber, D. A. (2010). Weather-related indices of autumn-winter dabbling duck abundance in middle North America. The Journal of Wildlife Management, 74(1), 94-101.

Thomas, C. D., et. al. (2012). Protected areas facilitate species' range expansions. Proceedings of the National Academy of Sciences, 109(35), 14063-14068.

Thomas, C. D., \& Lennon, J. J. (1999). Birds extend their ranges northwards. Nature, 399(6733), 213.

Tittensor, D. P., et al. (2014). A mid-term analysis of progress toward international biodiversity targets. Science, 346(6206), 241-244.

Trouwborst, A. (2009). International nature conservation law and the adaptation of biodiversity to climate change: a mismatch?. Journal of Environmental Law, 21(3), 419-442.

Trouwborst, A. (2011). Conserving European biodiversity in a changing climate: The Bern convention, the European Union Birds and Habitats Directives and the adaptation of nature to climate change. Review of European Community \& International Environmental Law, 20(1), 62-77.

Trouwborst, A. (2012). Transboundary wildlife conservation in a changing climate: adaptation of the Bonn Convention on Migratory Species and its daughter instruments to climate change. Diversity, $4(3), 258-300$. 
1. Simulations of the species extinction/colonization in response to temperature increase and subsequent changes of Community Temperature Index (CTI) and standard deviation (CTIsd) over time.

Following the Figure 1, four scenarios were simulated (Rcode below). The scenarios were: (1) 'No colonization-No extinction'; (2) 'Extinction only'; (3) 'Colonization only'; (4) 'Colonization-Extinction'.

625

626

627

628

629

630

631

632

633

634

635

636

For each of the four scenarios, we simulated an occurrence matrix for 100 species considered in three temperature dwelling classes over 25 years (from 1 to 25) and 100 sites. We attributed different Species Temperature Index (STI) values to the species from a random simulation of STI values based on a Gaussian distribution of mean 0 and SD 10. Twenty five species were considered as extreme cold-dwelling species with STI inferior to $-5^{\circ} \mathrm{C}, 50$ species were considered as slight coldor warm-dwelling species with STI between $-5^{\circ} \mathrm{C}$ and $5^{\circ} \mathrm{C}$ and 25 species were considered as extreme warm dwelling species with STI superior to $5^{\circ} \mathrm{C}$. Species occurrence were simulated from a binomial distribution with different probabilities between the extreme cold-dwelling $(p=0.25$ or $p=0.25$ year/100, if extinction), slight cold- or warm-dwelling species $(p=0.75)$ and extreme warm-dwelling species ( $p=0$ or $p=y e a r / 100$, if colonization). From the 100 original species pool, 1 to 90 species were randomly removed in order to simulated different environmental filters. We computed the CTI and $\mathrm{CTI}_{\text {sd }}$ values per year per site (see Methods). We used generalized linear mixed effects models (GLMM, Gaussian error distribution) with the CTI or CTIsd as the response variable, the year as the explanatory term and the site in random effect. Finally, the estimate temporal slope and its $p$-value were collected. We simulated the four scenarios 100 times following this process (Rcode below).

Rcode used for the simulations:

library(gImmTMB);library(dplyr);library(effects);library(ggplot2);library(ggpubr)

CTIcalc<-function $(x)\{\operatorname{sum}(\log (x+1) * S T I /$ sum $(\log (x+1)))\}$

CTIsdcalc_occ<-function $(x)\left\{a<-S T I^{*} x ; a[a==0]<-N A ; s d(a, n a . r m=T)\right\}$

M_CTItot=as.data.frame $($ matrix $(n r=4, n c=2)) ; M \_C T I s d=a s$. data.frame $($ matrix $(n r=4, n c=2))$

M_Simul_CTItot=NULL;M_Simul_CTIsd=NULL

\section{\# STI simulations}

for(s in 1:100)\{

STK<-as.data.frame(sort(rnorm $(1000$, mean $=0, s d=10)))$

STIwarm<-sort(sample(STI[STI>5], 25))

STImid<-sort(sample(STI[STI>(-5)\&STI<5], 50))

STIcold<-sort(sample(STI[STK<(-5)], 25))

L_model_occ<-list()

for(model in 1:4)\{

warm $=$ cold $<$-as. data. frame (matrix $(\mathrm{nc}=25, \mathrm{nr}=25 * 100)$ )

mid<-as.data. frame (matrix $(n c=50, n r=25 * 100)$ ) 
colnames(warm)<-rep(paste0("warm",1:25)); colnames(mid)<-rep(paste0("mid",1:50));colnames(cold)<rep(paste0("cold",1:25))

\#Cold-dwelling species occurrence

tempo<-NULL

for(i in 1:100)\{

tempo<-subset(cold[,1:25],cold\$site==site[i])

for $(k$ in $1: 25)\{$

for(j in 1:25)\{

proba_cold $<-c(0.25,(0.25-\mathrm{j} / 100), 0.25,(0.25-\mathrm{j} / 100))$

proba<-proba_cold[model]

proba[proba $<0]<-0$

tempo[j,k]<-rbinom(1,1,prob=proba)

\} \}

tempo_cold<-rbind(tempo_cold,tempo) \}

\section{\#Slight cold- and warm-dwelling species occurrence}

tempo<-NULL

for(i in 1:100)\{

tempo<-subset(mid[,1:50], mid\$site==site[i])

for $(k$ in $1: 50)\{$

for $(j$ in $1: 25)\{$

tempo[j,k]<-rbinom(1,1,prob=0.75)

\} \} tempo_mid<-rbind(tempo_mid,tempo) \}

\section{\#Warm-dwelling species occurrence}

tempo<-NULL

for(i in 1:100)\{

tempo<-subset(warm[,1:25], warm\$site==site[i])

for $(k$ in $1: 25)\{$

for(j in $1: 25)\{$

proba_warm<-c $(0,0,(\mathrm{j} / 100),(\mathrm{j} / 100))$

proba<-proba_warm[model]

proba[proba $<0]<-0$

tempo[j,k]<-rbinom $(1,1$, prob=proba $)$

\} \}

tempo_warm<-rbind(tempo_warm,tempo) \}

\section{\#Random species exclusion}

warm[,1:25]<-tempo_warm;tab_cti1<-as.data.frame(cbind(tempo_cold,tempo_mid,warm))

tab_cti=tempo=NULL

for(i in 1:100)\{

tempo<-subset(tab_cti1[,1:100],tab_cti1\$site==site[i]) tempo[,c(sample(1:100, sample $(1: 90,1)$, replace $=F))]<-0$ tab_cti<-rbind(tab_cti,tempo) \}

\section{\#Model}

tab_cti\$site<-tab_cti1\$site;tab_cti\$year<-tab_cti1\$year

STI<-c(STIcold,STImid,STIwarm)

tab_cti\$SCTItot<-apply(tab_cti[,1:100],1,CTIcalc); tab_cti\$SCTIsd<-apply(tab_cti[,1:100],1,CTIsdcalc_occ) L_model_occ[[model]]<-tab_cti

CTI_year<-glmmTMB(CTItot ${ }^{\sim}$ year+(1|site), family=gaussian(link = "identity"),data=L_model_occ[[model]]) 
bioRxiv preprint doi: https://doi.org/10.1101/2021.04.26.441480; this version posted April 27, 2021. The copyright holder for this preprint (which was not certified by peer review) is the author/funder. All rights reserved. No reuse allowed without permission.

M_CTItot[model,1:2]<-summary(CTI_year)\$coefficients\$cond $[c(2,8)]$

M_CTIsd[model,1:2]<-summary(CTI_year_sd)\$coefficients\$cond[c(2,8)]\}

M_Simul_CTItot<-rbind(M_Simul_CTItot,M_CTItot)

M_Simul_CTIsd<-rbind(M_Simul_CTIsd,M_CTIsd) \}

M_Simul_CTI<-as.data.frame(cbind(M_Simul_CTItot,M_Simul_CTIsd))

\section{A) CTI - Slope}
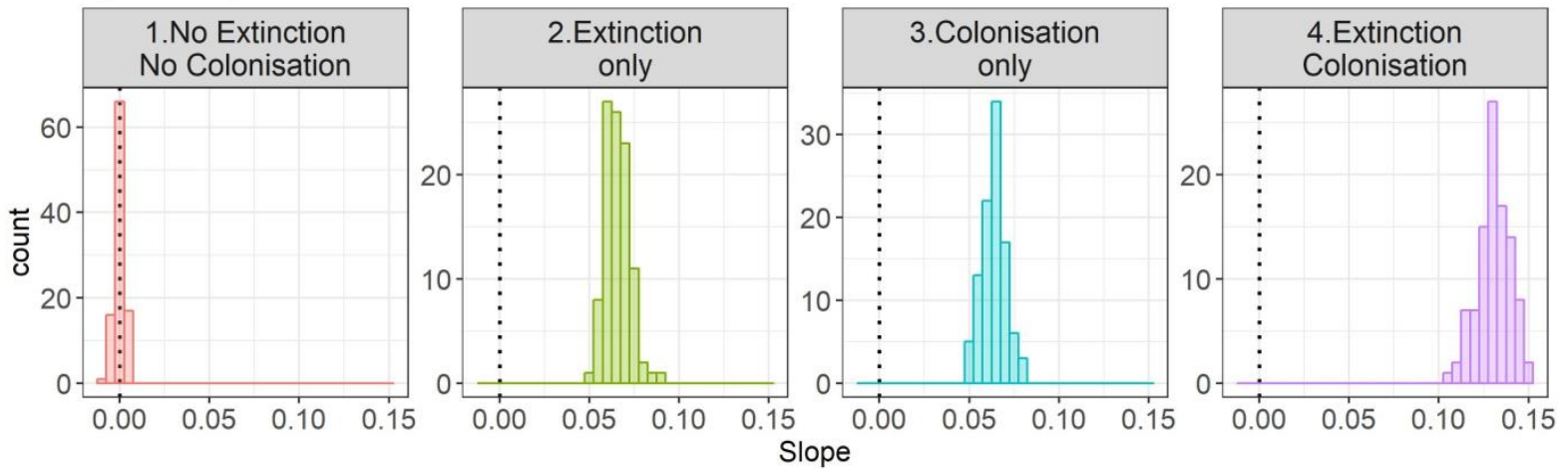

B) CTI - p-value
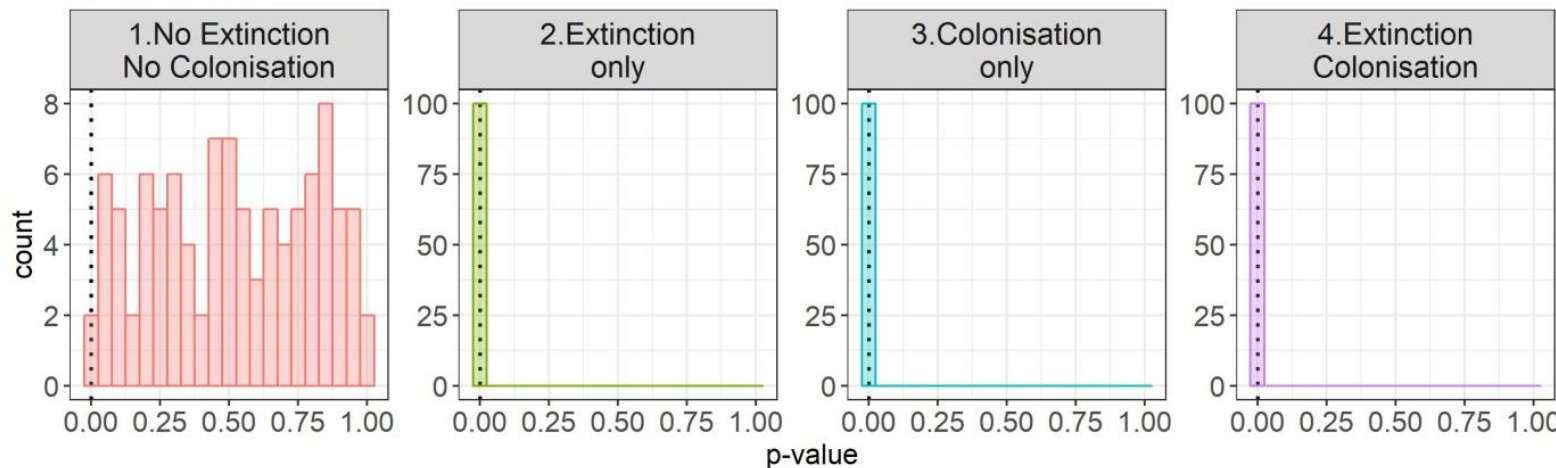

C) CTIsd - Slope
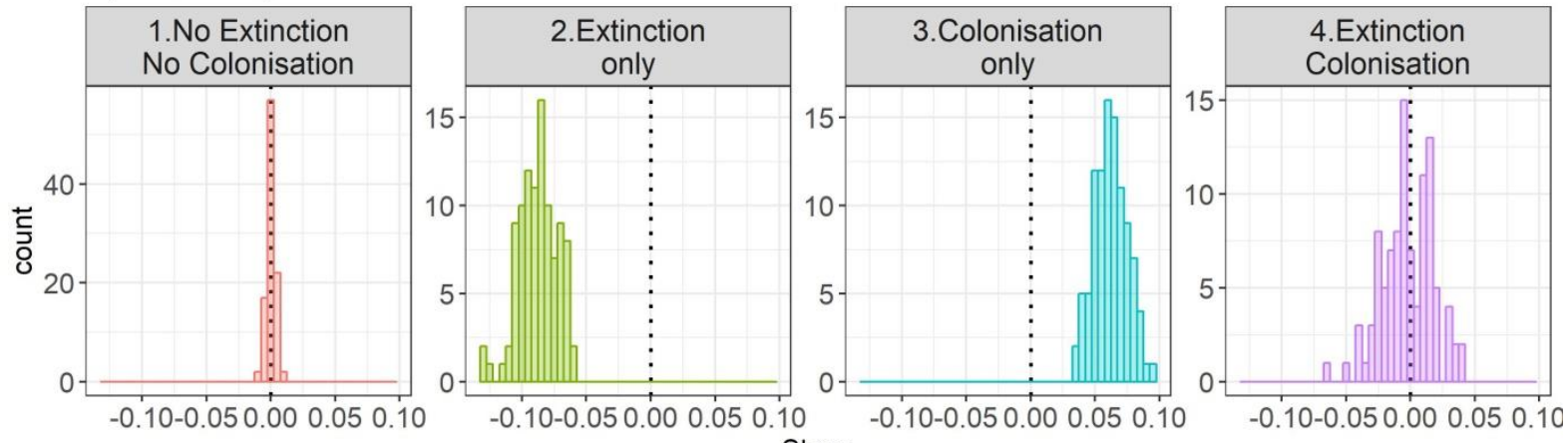

D) CTIsd - p-value

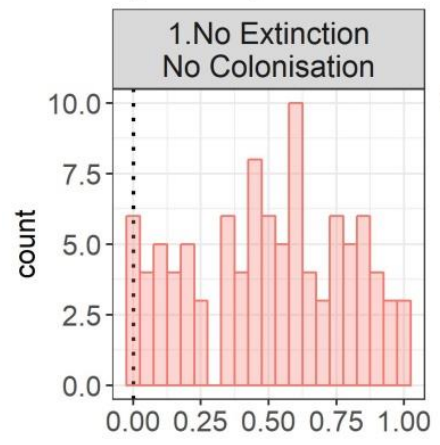

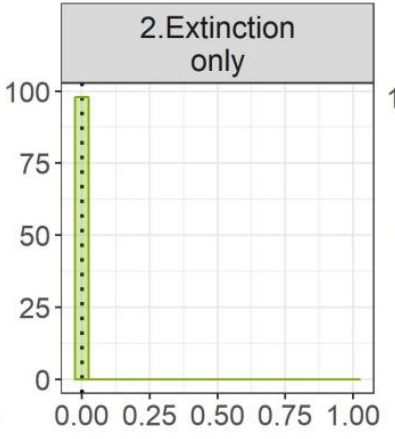
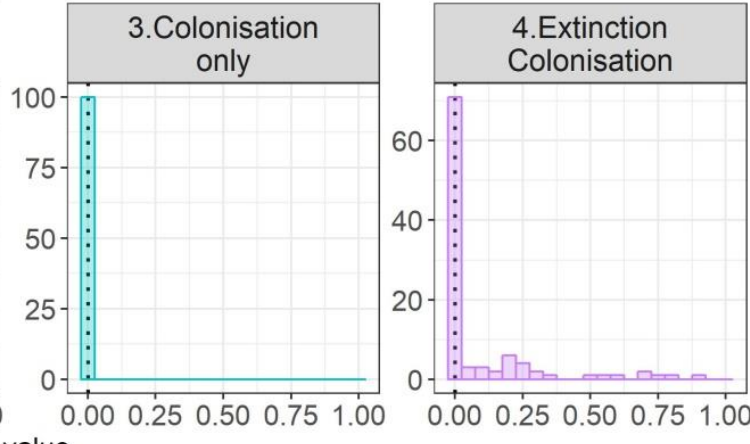

$\mathrm{p}$-value 
Figure S1a: Histograms of the model outputs per scenario. A) CTI estimated slope, B) p-value corresponding to the CTI slope, C) CTIsd estimated slope, D p-value corresponding to the CTIsd slope. The scenarios of community changes in response to temperature increase were: (1) 'No colonization-No extinction'; (2) 'Extinction only'; (3) 'Colonization only'; (4) ‘Colonization-Extinction'.

2. Empirical observation of waterbird species extinction/colonization in response to temperature increase and subsequent changes of Community Temperature Index average (CTI) and standard deviation $\left(\mathrm{CTI}_{s d}\right)$ over time.

We highlighted the ability of the $\mathrm{CTI}_{s d}$ to be an indicator of colonization and extinction processes in response to climate warming. Indeed, community changes in response to temperature increase should result in four scenarios: (1) 'No colonization-No extinction' causes no CTI and CTI sd changes; (2) 'Extinction only' causes CTI increase and $\mathrm{CTI}_{\text {sd }}$ decrease by the loss of cold-dwelling species; (3) 'Colonization only' causes $\mathrm{CTI}$ and $\mathrm{CTI}_{s d}$ increase by the gain of warm-dwelling species; (4) 'Colonization-Extinction' causes CTI increase by the species thermal turn-over, but no $\mathrm{CTI}_{\text {sd }}$ directional change (Fig. 1). We classified the count events in the four scenarios of colonization and/or extinction events, following what happening between the monitoring year and the next one (e.g., if between the counts $i$ and $i+1$ only one species colonized the site, the count $i$ correspond to the scenario (3) 'Colonization only'). For each count event, we measure the change of $\mathrm{CTI}_{\text {sd }}$ from a monitoring year and the next one (i.e., $\Delta \mathrm{CTI}_{\mathrm{sd}}$ ), which is supposed to be superior, inferior or equal to zero depending of the four colonization/extinction scenarios in response to temperature increase. We used a GLMM per scenarios (Gaussian error distribution) to investigate if the $\Delta C \mathrm{CI}_{\mathrm{sd}}$ values correspond to the expected patterns following the four scenarios. Site was added in random factors.

Conformely to the expectation under a community adjustment to climate warming, the $\Delta C \mathrm{CI}_{\mathrm{sd}}$ values was null in case of no extinction and no colonization $(\beta=0.000, P=1)$, significantly negative in case of extinction only $(\beta=-0.582, P<0.001)$, significantly positives in case of colonization only $(\beta=$ $0.590, P<0.001)$, and not significantly different from zero in case of extinction and colonization $(\beta=$ $-0.005, P=0.5)$ (Fig. S1b). 

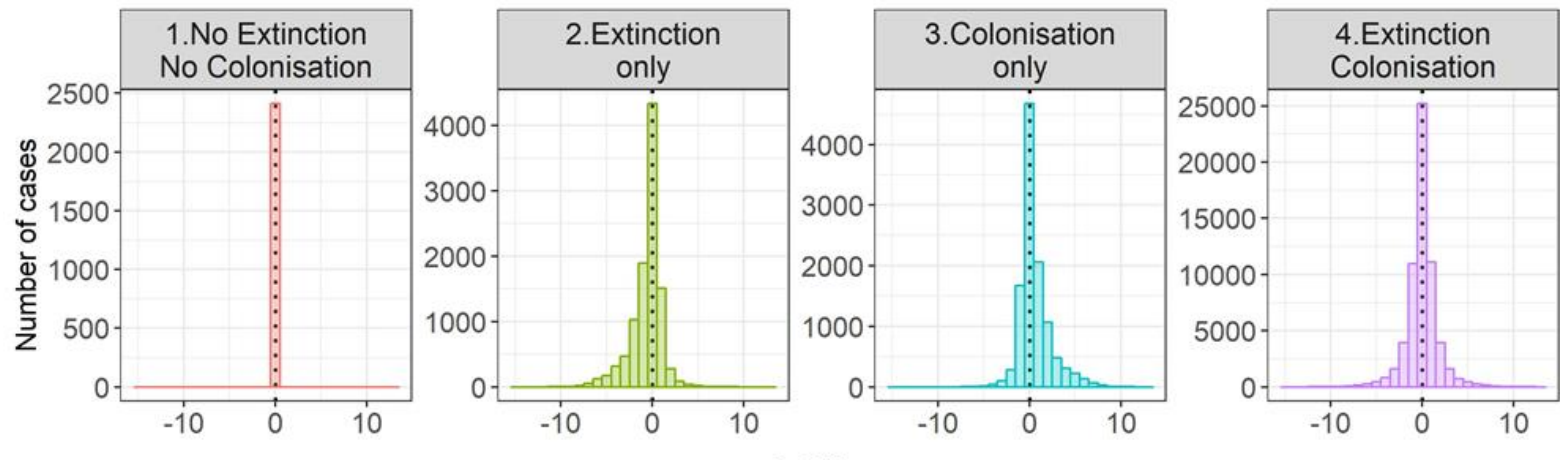

$\Delta C T I s d$

751

752 Figure $\mathrm{S} 1 \mathrm{~b}$ : Histograms of the $\Delta \mathrm{CTI}_{\mathrm{sd}}$ values over the four scenarios of community changes in

753 response to climate warming: (1) 'No colonization-No extinction' causes no $\mathrm{CTI}_{\text {sd }}$ changes, (2)

754 'Extinction only' causes $\mathrm{CTI}_{\text {sd }}$ decrease by the loss of cold-dwelling species, (3) 'Colonization only'

755 causes $\mathrm{CTI}_{\text {sd }}$ increase by the gain of warm-dwelling species, (4) 'Colonization-Extinction' causes no

$756 \mathrm{CTI}_{\text {sd }}$ directional change (Fig. 1). The dotted line is positioned on the zero to signify the absence of

$757 \mathrm{CTI}_{\text {sd }}$ change. 
Appendix 2. Details of the monitoring per country

\begin{tabular}{|c|c|c|c|c|c|c|}
\hline Country & $\begin{array}{l}\text { Number of } \\
\text { sites }\end{array}$ & $\begin{array}{c}\text { Average } \\
\text { number of } \\
\text { monitoring } \\
\text { years }\end{array}$ & $\begin{array}{l}\text { Average } \\
\text { covered } \\
\text { period }\end{array}$ & $\begin{array}{c}\text { Number of } \\
\text { sites included } \\
\text { in a protected } \\
\text { area }\end{array}$ & $\begin{array}{c}\text { Total } \\
\text { waterbird } \\
\text { abundance } \\
\text { (million) }\end{array}$ & $\begin{array}{r}\text { Monitoring } \\
\text { changes }\end{array}$ \\
\hline Albania & 13 & 14.6 & 22.8 & 10 & 2.67 & No \\
\hline Algeria & 75 & 15.7 & 22.0 & 42 & 4.08 & No \\
\hline Austria & 174 & 20.4 & 22.8 & 68 & 2.76 & No \\
\hline Belarus & 4 & 8.3 & 20.5 & 1 & 0.10 & No \\
\hline Belgium:Flanders & 472 & 19.8 & 22.6 & 234 & 5.83 & Yes \\
\hline Belgium:Wallonia & 180 & 13.0 & 15.9 & 48 & 0.71 & No \\
\hline Bosnia \& Herzegovina & 1 & 11.0 & 16.0 & 0 & 0.02 & No \\
\hline Bulgaria & 46 & 18.7 & 22.2 & 36 & 6.90 & No \\
\hline Croatia & 32 & 11.5 & 21.5 & 26 & 1.50 & No \\
\hline Cyprus & 12 & 15.8 & 22.4 & 8 & 0.27 & No \\
\hline Czechia & 215 & 15.7 & 22.3 & 60 & 2.38 & No \\
\hline Denmark & 48 & 22.1 & 23.5 & 35 & 6.21 & Yes \\
\hline Estonia & 4 & 19.0 & 19.5 & 3 & 0.06 & No \\
\hline Finland & 172 & 15.9 & 21.5 & 101 & 0.89 & No \\
\hline France & 291 & 22.3 & 23.3 & 137 & 52.60 & No \\
\hline Germany & 1057 & 15.6 & 19.1 & 749 & 35.02 & No \\
\hline Greece & 92 & 13.0 & 19.2 & 72 & 8.26 & No \\
\hline Hungary & 25 & 17.1 & 20.9 & 19 & 2.91 & No \\
\hline Ireland & 255 & 14.4 & 19.3 & 61 & 6.02 & Yes \\
\hline Italy & 458 & 17.9 & 20.7 & 241 & 32.84 & No \\
\hline Latvia & 144 & 13.5 & 22.1 & 71 & 0.82 & No \\
\hline Lithuania & 5 & 13.6 & 22.2 & 4 & 0.78 & No \\
\hline Montenegro & 1 & 22.0 & 24.0 & 1 & 2.90 & No \\
\hline Morocco & 65 & 11.9 & 21.6 & 36 & 6.66 & No \\
\hline Netherlands & 173 & 23.8 & 22.9 & 59 & 98.62 & No \\
\hline North Macedonia & 2 & 13.5 & 20.0 & 2 & 0.55 & No \\
\hline Norway & 57 & 16.6 & 23.5 & 28 & 0.36 & No \\
\hline Poland & 12 & 10.5 & 21.5 & 10 & 0.22 & No \\
\hline Portugal & 13 & 17.3 & 22.5 & 11 & 2.66 & No \\
\hline Romania & 34 & 11.1 & 17.5 & 34 & 1.75 & Yes \\
\hline Serbia & 2 & 5.5 & 20.5 & 0 & 0.07 & No \\
\hline Slovakia & 80 & 10.8 & 14.5 & 39 & 0.82 & No \\
\hline Slovenia & 2 & 16.5 & 20.5 & 2 & 0.04 & No \\
\hline Spain & 780 & 13.5 & 19.2 & 351 & 23.63 & No \\
\hline Sweden & 705 & 17.6 & 22.7 & 243 & 8.64 & Yes \\
\hline Switzerland & 100 & 22.6 & 23.2 & 24 & 13.40 & No \\
\hline Tunisia & 31 & 10.9 & 22.9 & 11 & 3.27 & No \\
\hline Turkey & 45 & 7.8 & 19.1 & 5 & 8.65 & No \\
\hline Ukraine & 11 & 9.7 & 17.7 & 8 & 1.70 & No \\
\hline United Kingdom & 1615 & 18.0 & 21.1 & 660 & 50.07 & Yes \\
\hline
\end{tabular}


Appendix 3. Additional species information.

The winter STI is the long-term average January temperature (WorldClim database, 1950-2000, http://worldclim.org/) experimented by the species across its non-breeding (overwintering) distribution (extracted from www.birdlife.org 2015) only inside the African-Eurasian region defined by the African-Eurasian Migratory Waterbird Agreement (AEWA, http://www.unep-aewa.org). We removed the distribution of the sub-species resident in sub-Saharan Africa to avoid an overestimation of the thermal affinity tolerated by the studied populations (Involved species: Ardea alba, Ardea cinerea, Botaurus stellaris, Gallinula chloropus, Phalacrocorax carbo, Podiceps cristatus, Podiceps nigricollis, Porphyrio porphyrio and Tachybaptus ruficollis). Species considered as vagrant when their overwintering distribution was not included in the AEWA area and in the WesternPalearctic with a minimum threshold of 500 individuals over the 25 years.

Table S2: List of the species with their species temperature index (STI) and the number of sites occupied at least once.

\begin{tabular}{lrr} 
Scientific name & \multicolumn{1}{c}{ STI } & Number of sites occupied \\
Actitis hypoleucos & 23.16 & 1274 \\
Anas acuta & 16.90 & 2696 \\
Anas clypeata & 14.91 & 4929 \\
Anas crecca & 12.72 & 6854 \\
Anas penelope & 16.53 & 1642 \\
Anas platyrhynchos & -0.02 & 3770 \\
Anas strepera & 11.73 & 734 \\
Anser albifrons & 2.53 & 93 \\
Anser anser & 4.47 & 1229 \\
Anser brachyrhynchus & 2.02 & 2246 \\
Anser erythropus & 2.43 & 6239 \\
Anser fabalis & -2.51 & 586 \\
Ardea alba & 5.41 & 4994 \\
Ardea cinerea & 4.32 & 5303 \\
Arenaria interpres & 17.86 & 1696 \\
Aythya ferina & 11.34 & 744 \\
Aythya fuligula & 10.45 & 857 \\
Aythya marila & 0.43 & 577 \\
Aythya nyroca & 9.77 & 1444 \\
Botaurus stellaris & 17.73 & 182 \\
Branta bernicla & 2.86 & 853 \\
Branta leucopsis & 1.69 & 4057 \\
Branta ruficollis & 1.10 & 539 \\
Bubulcus ibis & 22.96 & 1297 \\
Bucephala clangula & -1.11 & 420 \\
Calidris alba & 18.86 & 254 \\
Calidris alpina & 11.83 & 467 \\
Calidris canutus & 19.08 & 550 \\
Calidris maritima & -2.48 & 498 \\
Calidris minuta & 22.77 & 697 \\
Charadrius alexandrinus & 19.20 & 630
\end{tabular}




\begin{tabular}{|c|c|c|}
\hline Charadrius hiaticula & 22.11 & 1103 \\
\hline Ciconia ciconia & 22.95 & 707 \\
\hline Clangula hyemalis & -2.50 & 2258 \\
\hline Cygnus columbianus & 2.44 & 5300 \\
\hline Cygnus cygnus & -1.49 & 1796 \\
\hline Cygnus olor & 1.27 & 5837 \\
\hline Egretta garzetta & 21.26 & 65 \\
\hline Fulica atra & 5.86 & 2653 \\
\hline Fulica cristata & 22.59 & 4535 \\
\hline Gallinula chloropus & 5.61 & 862 \\
\hline Gallinago gallinago & 18.58 & 944 \\
\hline Gavia arctica & 0.76 & 581 \\
\hline Gavia stellata & 3.05 & 949 \\
\hline Grus grus & 14.72 & 379 \\
\hline Haematopus ostralegus & 15.34 & 549 \\
\hline Himantopus himantopus & 22.13 & 4140 \\
\hline Larus minutus & 3.70 & 172 \\
\hline Larus argentatus & 4.58 & 3413 \\
\hline Larus audouinii & 11.45 & 2046 \\
\hline Larus canus & 1.62 & 207 \\
\hline Larus fuscus & 18.58 & 1707 \\
\hline Larus genei & 11.90 & 607 \\
\hline Larus marinus & -2.49 & 4695 \\
\hline Larus melanocephalus & 9.31 & 478 \\
\hline Larus ridibundus & 6.58 & 596 \\
\hline Limosa lapponica & 19.23 & 4323 \\
\hline Limosa limosa & 21.01 & 3760 \\
\hline Marmaronetta angustirostris & 5.95 & 87 \\
\hline Melanitta fusca & 0.67 & 904 \\
\hline Melanitta nigra & 2.28 & 838 \\
\hline Mergellus albellus & -1.58 & 2396 \\
\hline Mergus merganser & -0.40 & 3945 \\
\hline Mergus serrator & -1.08 & 1911 \\
\hline Phalacrocorax pygmeus & 2.74 & 286 \\
\hline Netta rufina & 5.35 & 1208 \\
\hline Numenius arquata & 18.89 & 1738 \\
\hline Numenius phaeopus & 22.06 & 228 \\
\hline Nycticorax nycticorax & 23.47 & 218 \\
\hline Oxyura leucocephala & 1.27 & 168 \\
\hline Pelecanus crispus & 8.37 & 116 \\
\hline Pelecanus onocrotalus & 22.01 & 71 \\
\hline Phalacrocorax aristotelis & 2.30 & 499 \\
\hline Phalacrocorax carbo & 3.70 & 6160 \\
\hline Philomachus pugnax & 22.96 & 465 \\
\hline Phoenicopterus roseus & 20.58 & 440 \\
\hline Platalea leucorodia & 17.95 & 192 \\
\hline Plegadis falcinellus & 23.14 & 1269 \\
\hline Pluvialis apricaria & 5.36 & 692 \\
\hline
\end{tabular}


Pluvialis squatarola

Podiceps auritus

Podiceps cristatus

Podiceps grisegena

Podiceps nigricollis

Porphyrio porphyrio

Rallus aquaticus

Recurvirostra avosetta

Somateria mollissima

Tachybaptus ruficollis

Tadorna ferruginea

Tadorna tadorna

Sterna sandvicensis

Tringa erythropus

Tringa nebularia

Tringa ochropus

Tringa totanus

Vanellus vanellus
18.84

3.39

3.25

2.27

6.63

8.20

4.52

22.04

$-7.53$

3.54

8.88

4.30

12.38

21.03

23.16

21.10

15.48

4.52
742

4742

798

1256

253

1810

563

1094

3114

4917

500

2444

422

473

748

1475

1412

2933 
Appendix 4: Additional monitoring information and CTI correction.

The International Waterbird Census (IWC) started for some species in the 1960s, but had comprehensive species coverage by the end of the 1980s. To be cautious, we started the study period in 1993. However, in some countries gulls and shags were not included directly in the IWC. The full waterbird species census was performed later in Romania (1999), Belgium (Flandre, 2000), Denmark (2001), United Kingdom (2002), Ireland (2002) and Sweden (still not full). As a change in species monitored can artificially affect the community changes, we took these dates into account in the analyses.

The community temperature index (CTI) was corrected to account for the monitoring changes in countries where the full waterbird species census started after the beginning of the study period (countries listed above). In these countries, the CTI values before the year(s) of monitoring change were centred per site (not reduced) and added to the average site CTI value of the years after the monitoring change. Hence, the addition of new species after the monitoring change doesn't strongly affect the CTI values (Appendix 4, Table S1). Note that under the hypothesis of a CTI increase over years, the CTI correction leads to an overestimation of the site CTI average before the monitoring change. Regarding the $\mathrm{CTI}_{\text {sd }}$ no adaptation was done.

Table S1: Summary of the variance minimum (Min.) median, mean and maximum (Max.) between the original CTI computed without and with correction.

\begin{tabular}{lrrrr}
\hline Variable & Min. & \multicolumn{2}{c}{ Median } & \multicolumn{2}{c}{ Mean } & \multicolumn{2}{c}{ Max. } \\
\hline CTI uncorrected & -5.014 & 5.392 & 5.514 & 22.544 \\
CTI corrected & -5.014 & 5.382 & 5.516 & 22.544 \\
\hline
\end{tabular}

We performed models with the full dataset and the data subset to control the potential differences. We used the same model framework as in the Methods section to evaluate the change of CTI, CTI $I_{\text {sd }}$, number of cold-dwelling species and number of warm-dwelling species. As a result, the models outputs were fairly similar between the two dataset, at the exception that warm-dwelling species did not significantly increased more than cold-dwelling species inside PAs (Appendix 4, Table S2). 
805

806

807

808

809

Table S2: Comparison of the models with the full dataset and the subset of data with the full species monitoring. Protected area (PA) effect on temporal trends of the community temperature index (CTI) and standard deviation of the CTI (CTI $\left.I_{\text {sd }}\right)$, number of cold- and warm-dwelling species. Base line is sites outside PA and cold-dwelling species. Years were standardized to zero mean (std.) in the thermal-dwellers model and interactions are notified by ' $:$ '.

\begin{tabular}{|c|c|c|c|c|c|c|}
\hline Dataset & Variable & Parameter & Coefficient & SE & Z-value & P-value \\
\hline \multirow{16}{*}{ Full dataset } & \multirow{4}{*}{ CTI } & Intercept & -6.030 & 1.696 & -3.554 & $<0.001$ \\
\hline & & Year & 0.006 & 0.001 & 6.676 & $<0.001$ \\
\hline & & PA & 7.972 & 2.435 & 3.274 & $<0.001$ \\
\hline & & Year:PA & 0.004 & 0.001 & 3.412 & $<0.001$ \\
\hline & \multirow{4}{*}{$\mathrm{CTI}_{\mathrm{sd}}$} & Intercept & 4.294 & 1.602 & 2.680 & 0.007 \\
\hline & & Year & 0.000 & 0.001 & 0.360 & 0.719 \\
\hline & & PA & 11.310 & 2.300 & 4.920 & $<0.001$ \\
\hline & & Year:PA & 0.006 & 0.001 & 5.066 & $<0.001$ \\
\hline & \multirow{8}{*}{$\begin{array}{c}\text { Cold- and } \\
\text { Warm-dwellers }\end{array}$} & Intercept & 1.466 & 0.012 & 125.070 & $<0.001$ \\
\hline & & Year(std.) & 0.057 & 0.002 & 33.560 & $<0.001$ \\
\hline & & PA & 0.163 & 0.017 & 9.600 & $<0.001$ \\
\hline & & Dweller & 0.338 & 0.002 & 154.600 & $<0.001$ \\
\hline & & Year(std.):PA & 0.005 & 0.002 & 2.360 & 0.018 \\
\hline & & Year(std.):Dweller & 0.008 & 0.002 & 3.820 & $<0.001$ \\
\hline & & PA:Dwellers & 0.022 & 0.003 & 7.360 & $<0.001$ \\
\hline & & Year(std.):PA:Dweller & 0.006 & 0.003 & 1.960 & 0.050 \\
\hline \multirow{16}{*}{$\begin{array}{l}\text { Subset with } \\
\text { full species } \\
\text { monitoring }\end{array}$} & \multirow{4}{*}{ CTI } & Intercept & 0.098 & 2.241 & 0.044 & 0.965 \\
\hline & & Year & 0.003 & 0.001 & 2.563 & 0.010 \\
\hline & & PA & 15.302 & 3.123 & 4.900 & $<0.001$ \\
\hline & & Year:PA & 0.008 & 0.002 & 4.930 & $<0.001$ \\
\hline & \multirow{4}{*}{$\mathrm{CTI}_{\mathrm{sd}}$} & Intercept & 2.396 & 2.051 & 1.168 & 0.243 \\
\hline & & Year & 0.001 & 0.001 & 1.290 & 0.197 \\
\hline & & PA & 8.743 & 2.858 & 3.059 & 0.002 \\
\hline & & Year:PA & 0.004 & 0.001 & 3.153 & 0.002 \\
\hline & \multirow{8}{*}{$\begin{array}{c}\text { Cold- and } \\
\text { Warm-dwellers }\end{array}$} & Intercept & 1.473 & 0.012 & 124.750 & $<0.001$ \\
\hline & & Year(std.) & 0.049 & 0.002 & 26.090 & $<0.001$ \\
\hline & & PA & 0.166 & 0.017 & 9.720 & $<0.001$ \\
\hline & & Dweller & 0.334 & 0.002 & 141.280 & $<0.001$ \\
\hline & & Year(std.):PA & 0.008 & 0.003 & 3.060 & 0.002 \\
\hline & & Year(std.):Dweller & 0.014 & 0.002 & 6.020 & $<0.001$ \\
\hline & & PA:Dwellers & 0.024 & 0.003 & 7.460 & $<0.001$ \\
\hline & & Year(std.):PA:Dweller & 0.005 & 0.003 & 1.620 & 0.104 \\
\hline
\end{tabular}


812 Appendix 5: Protected area surfaces in the study area. Protected area surface $\left(\mathrm{km}^{2}\right)$ is represented 813 by points located at the centre of the corresponding cell $\left(5^{\circ} \times 5^{\circ}\right.$ resolution), which include both 814 protected and not protected sites and at least 15 sites. The protected area surface corresponds to the sum of the PA surfaces per cell. The size of the points indicates the protected area surface size.

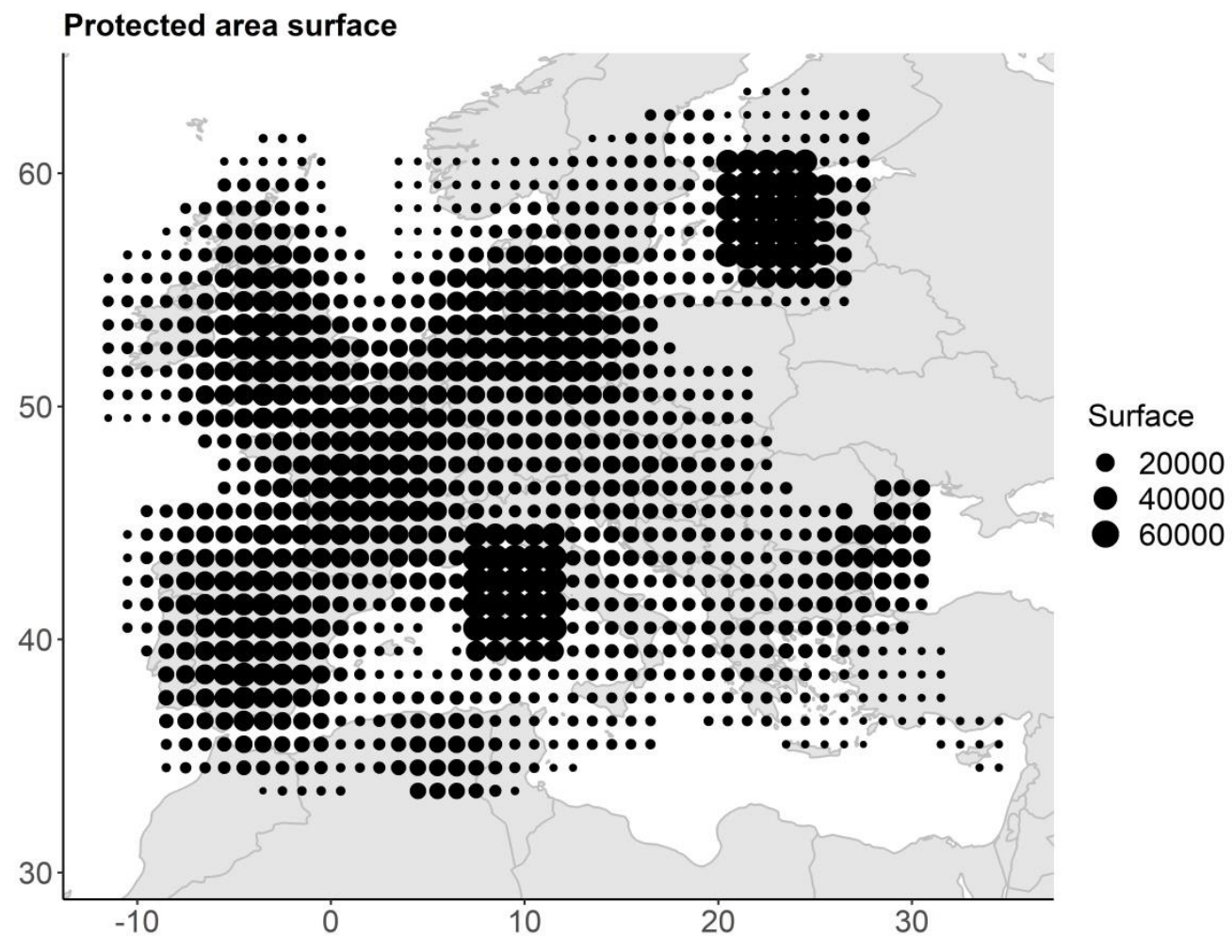

